\title{
Looking Back on Contributions in the Field of Atmospheric Corrosion Offered by the MICAT Ibero-American Testing Network
}

\author{
M. Morcillo, B. Chico, D. de la Fuente, and J. Simancas \\ Ingeniería de Superficies, Corrosión y Durabilidad, Centro Nacional de Investigaciones Metalúrgicas (CENIM, CSIC), \\ Avenida Gregorio del Amo 8, 28040 Madrid, Spain \\ Correspondence should be addressed to M. Morcillo, morcillo@cenim.csic.es
}

Received 19 July 2011; Revised 10 October 2011; Accepted 25 October 2011

Academic Editor: Oladis Troconis de Rincon

Copyright ( $) 2012$ M. Morcillo et al. This is an open access article distributed under the Creative Commons Attribution License, which permits unrestricted use, distribution, and reproduction in any medium, provided the original work is properly cited.

The Ibero-American Map of Atmospheric Corrosiveness (MICAT) project was set up in 1988 sponsored by the International IberoAmerican programme "Science and Technology for Development (CYTED)" and ended in 1994 after six years of activities. Fourteen countries were involved in this project: Argentina, Brazil, Chile, Colombia, Costa Rica, Cuba, Ecuador, Mexico, Panama, Peru, Portugal, Spain, Uruguay, and Venezuela. Research was conducted both at laboratories and in a network of 75 atmospheric exposure test sites throughout the Ibero-American region, thus considering a broad spectrum of climatological and pollution conditions. Although with its own peculiarities, the project basically followed the outline of the ISOCORRAG and ICP/UNECE projects, with the aim of a desirable link between the three projects. This paper summarizes the results obtained in the MICAT project for mild steel, zinc, copper, and aluminum specimens exposed for one year in different rural, urban, and marine atmospheres in the Ibero-American region. Complementary morphological and chemical studies were carried out using scanning electron microscopy (SEM) coupled with energy dispersive spectrometry (EDS), X-ray diffraction (XRD), and fourier transform infrared Spectroscopy (FTIR) techniques, in order to correlate climatic and atmospheric conditions and properties of the corrosion products.

\section{Introduction}

During the 2nd Ibero-American Congress on Corrosion and Protection held in Maracaibo (Venezuela) in September 1986, a round-table was organized to discuss the idea of an Ibero-American Map of Atmospheric Corrosion (MICAT). Representatives of the countries present at the meeting expressed their interest in participating in such a project.

Moves were then made to include this proposal in the Ibero-American Programme Science and Technology for Development (CYTED). A year later, in January 1988, the Technical and Managing Council of CYTED, gathered in Havana (Cuba), decided to approve the inclusion of the MICAT study into the CYTED Programme. lows.

The primary aims of the MICAT study were $[1,2]$ as fol-

(1) To improve knowledge of the process of atmospheric corrosion in various climatic regions of Iberoamerica.
(2) By means of statistical treatment of the results to obtain mathematical expressions of the estimation of atmospheric corrosion as a function of climatic and pollution parameters.

(3) No less important was the objective of promoting international cooperation. In this respect, the building of bridges of understanding and the establishing of Ibero-American research groups have been achievements of deep and lasting significance, taking advantage of existing synergies and above all sharing knowledge and providing training for other countries less developed in the study of atmospheric corrosion. This research project was the first time in IberoAmerica that 14 countries had worked together towards a common goal in the field of corrosion.

The MICAT project was officially launched in Caracas in August 1988 and came to an end in Lisbon in December 1994, with meetings in Rio de Janeiro (1989), San Jose Costa 
Rica (1990), Marambio Argentine Antarctic Base (1991), Madrid (1992), and Santiago de Chile (1993).

Research was carried out in laboratories in the 14 participating countries (Argentina, Brazil, Colombia, Costa Rica, Chile, Ecuador, Mexico, Panama, Peru, Portugal, Spain, Uruguay, and Venezuela) and in a network of 72 atmospheric testing stations covering a broad spectrum of climatological and pollution conditions. Some 70 working groups comprising a total of 130 researchers took part in the project. The countries, organizations responsible, and contact persons are listed in Table 1.

The publication of preliminary results $[3,4]$ met with accolades throughout Ibero-America and received an NACE International award. A book has been published in Spanish and Portuguese [5] describing in more than 800 pages all the details and results obtained in the MICAT project. Likewise, several papers have been published in international journals, which describe in an ample way the main results obtained [617]. Some of the countries participating in the project have also published their own monographic studies: Spain [18], Argentina [19], Portugal [20], Mexico [21], and so forth.

This paper summarises the MICAT project's main contributions to knowledge of atmospheric corrosion.

\section{Experimental}

Although with its own peculiarities, the project basically followed the outline of the ISOCORRAG [22] and ICP/UNECE [23] projects, with the aim of a desirable link between the three projects. Standardized procedures ISO have been followed.

Figure 1 shows the location of the Ibero-American network of atmospheric corrosion test stations. The names and identification codes of the test are sites listed in Table 2. The network provides a variety of climatological and pollution conditions.

The atmosphere at each test site is characterized from meteorological and atmospheric pollution data (ISO 9223 [24]). The former include basically the temperature, relative humidity $(\mathrm{RH})$ of the air, and rainfall. These parameters are recorded at the station itself most lie in meteorological stations of the Meteorological Service of the country in question - or at a neighbouring meteorological station. The recorded thermohydrograms are used to show the time of wetness (TOW), the fraction of the year in which $\mathrm{RH}>$ $80 \%$ and $\mathrm{T}>0{ }^{\circ} \mathrm{C}$. The deposition rates of $\mathrm{SO}_{2}$ and chloride are measured following ISO 9225 [25]. Average annual environmental data have been published elsewhere [14].

The materials investigated are structural metals, in the form of flat plate specimens, with the following features: steel (unalloyed, low carbon), zinc (98.5\% min), copper $(99.5 \%$ min), and aluminum (99.5\% $\mathrm{min})$. The test specimens are usually $10 \times 15 \mathrm{~cm}^{2}$ and cut out from $1 \mathrm{~mm}$ thick sheets.

The exposure sequences include three one-year exposures, one two-year exposure, one three-year exposure, and one four-year exposure. In this paper only one-year exposures have been considered.

Four specimens of each material are exposed in each sequence, three of which are used to determine weight losses according ISO 9226 [26]. The removal of corrosion products by chemicals to determine the weight loss involves a loss of valuable information of the atmospheric corrosion process. Therefore, a fourth specimen of each sequence was used for laboratory studies: (a) analysis of the corrosion products by means of diverse experimental techniques: XRD, IR, Mössbauer spectroscopy, and so forth, and microscopical examination (surface and cross-section) of the morphology of the corrosion products layers.

2.1. Identification of Corrosion Products. The identification techniques used were basically the following: X-ray diffraction (XRD), infrared spectroscopy (IR), and Mössbauer Spectroscopy (only for the steel). In certain cases elemental information was also obtained by energy dispersive spectroscopy (EDS). The techniques used are complementary. The integration of all of them has permitted a more precise identification of the corrosion compounds formed.

2.2. Morphology of the Attack of the Base Metal and Microstructure of the Corrosion Products. This information was obtained from observation with the scanning electron microscope (SEM) of both the outer surface of the layer of corrosion products and cross-sections. In some cases elemental information was also obtained by EDS, as well as $\mathrm{X}$-ray mappings of certain chemical elements of interest (mainly $\mathrm{S}$ and $\mathrm{Cl}$ ).

\section{Main Results and Discussion}

In particular, attention is paid to the atmospheric corrosion of four reference metals: unalloyed carbon steel, zinc, copper, and aluminium.

The MICAT project gathered highly varied and complementary information that allowed an in-depth insight into the atmospheric corrosion mechanisms of these four metals. This data included atmospheric aggressivity factors (meteorological parameters, time of wetness (TOW), sulphur dioxide, and chloride deposition rates), the attack experienced by the materials in different atmospheres, the nature of the corrosion products formed on the metallic surface, the morphology of the corrosion films and products, and the morphology of the attack experienced by the base metals.

In order to address this analysis in a systematic way, reference was essentially made to international standard ISO 9223 [24], which classifies atmospheres by their TOW $(\tau)$ and the deposition rate of the most common pollutants: sulphur dioxide $(\mathrm{P})$ and atmospheric salinity $(\mathrm{S})$. Thus, the testing stations participating in the project were classified as shown in Table 3. Figure 2 gives an overview of the atmospheres considered in the research by $\mathrm{S}_{x} \mathrm{P}_{y}$ categories according to ISO 9223 [24]. As can be seen, the MICAT atmospheres cover the spectrum of rural and pure marine atmospheres fairly well and are sufficiently representative of marine atmospheres with low to moderate $\mathrm{SO}_{2}$ contents, but 
TABLE 1: Organizations participating in the MICAT Project.

\begin{tabular}{|c|c|c|}
\hline Country & Institution, organization & Contact person \\
\hline Argentina & $\begin{array}{l}\text { Instituto de Investigaciones Científicas y Técnicas de las Fuerzas } \\
\text { Armadas (CITEFA) }\end{array}$ & B. M. Rosales \\
\hline Brazil & Centro de Pesquisas de Energía Elétrica (CEPEL) & M. Marrocos \\
\hline Chile & $\begin{array}{l}\text { Universidad de Chile Instituto de Investigaciones y Ensayes de } \\
\text { Materiales (IDIEM) }\end{array}$ & G. Joseph \\
\hline Colombia & Universidad de Antioquia & A. Valencia \\
\hline Costa Rica & Instituto Tecnológico de Costa Rica (ITCR) & J. F. Álvarez \\
\hline Cuba & Centro de Investigaciones Químicas (CIQ) & A. Cabezas \\
\hline Ecuador & Escuela Superior Politécnica del Litoral (ESPOL) & J. Peña \\
\hline Mexico & Instituto de Investigaciones Eléctricas (IIE) & J. Uruchurtu \\
\hline Panama & Universidad de Panamá & A. F. de Bósquez \\
\hline Peru & $\begin{array}{l}\text { Instituto de Investigación Tecnológica Industrial de Normas Técnicas } \\
\text { (ITINTEC) }\end{array}$ & G. Salas \\
\hline \multirow{2}{*}{ Portugal } & Instituto Nacional de Engenharia e Tecnología Industrial (INETI) & E. M. Almeida \\
\hline & Instituto Superior Técnico (IST) & M. G. S. Ferreira \\
\hline Spain & Centro Nacional de Investigaciones Metalúrgicas (CENIM/CSIC) & M. Morcillo \\
\hline Uruguay & Universidad de la República Oriental del Uruguay (UROU) & S. Rivero \\
\hline \multirow{2}{*}{ Venezuela } & Universidad Nacional Experimental Francisco Miranda (UNEFM) & M. R. Prato \\
\hline & Universidad del Zulia & O. T. de Rincón \\
\hline
\end{tabular}

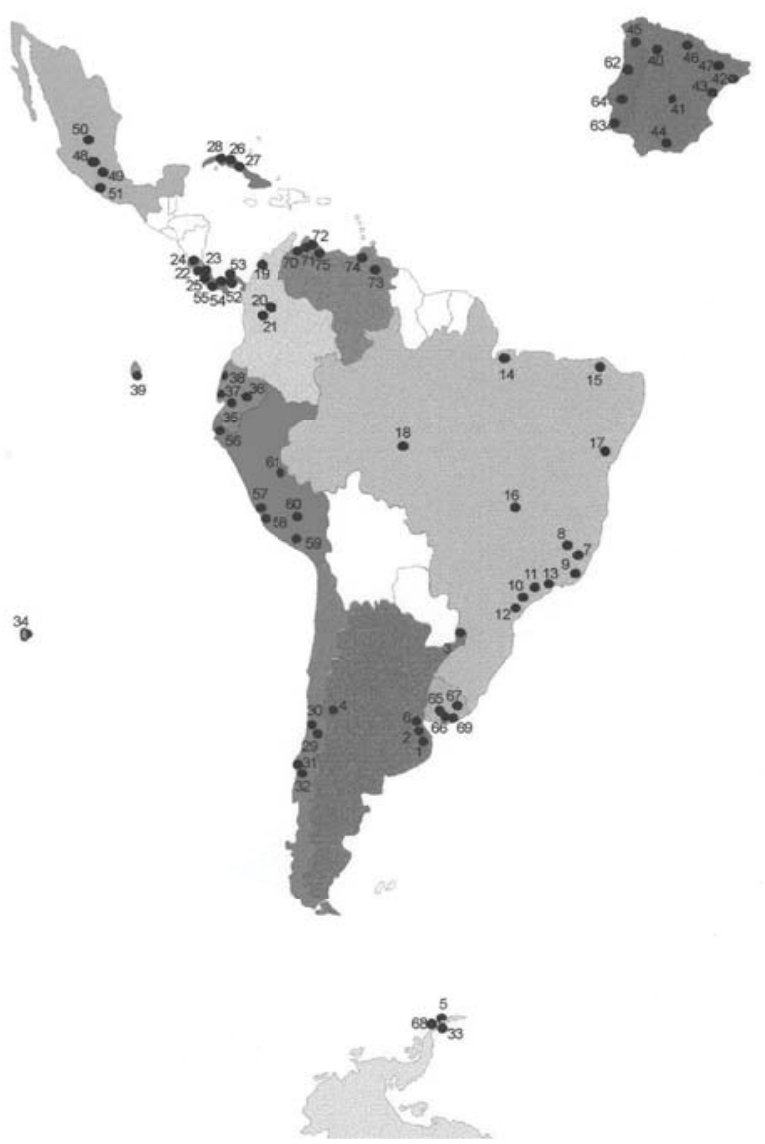

Figure 1: MICAT network of atmospheric corrosion stations. 
TABLE 2: List of MICAT test sites.

\begin{tabular}{|c|c|c|}
\hline Country & Code & Test site \\
\hline \multirow{6}{*}{ Argentina } & 1 & Camet \\
\hline & 2 & V. Martelli \\
\hline & 3 & Iguazú \\
\hline & 4 & San Juan \\
\hline & 5 & Jubani \\
\hline & 6 & La Plata \\
\hline \multirow{12}{*}{ Brazil } & 7 & Caratinga \\
\hline & 8 & Ipatinga \\
\hline & 9 & Arraial do Cabo \\
\hline & 10 & Cubatao \\
\hline & 11 & Ubatuba \\
\hline & 12 & São Paulo \\
\hline & 13 & Río de Janeiro \\
\hline & 14 & Belem \\
\hline & 15 & Fortaleza \\
\hline & 16 & Brasilia \\
\hline & 17 & P. Afonso \\
\hline & 18 & Porto Velho \\
\hline \multirow{3}{*}{ Colombia } & 19 & Isla Naval \\
\hline & 20 & San Pedro \\
\hline & 21 & Cotové \\
\hline \multirow{4}{*}{ Costa Rica } & 22 & Puntarenas \\
\hline & 23 & Limón \\
\hline & 24 & Arenal \\
\hline & 25 & Sabanilla \\
\hline \multirow{3}{*}{ Cuba } & 26 & Ciq \\
\hline & 27 & Cojímar \\
\hline & 28 & Bauta \\
\hline \multirow{6}{*}{ Chile } & 29 & Cerrillos \\
\hline & 30 & Valparaíso \\
\hline & 31 & Idiem \\
\hline & 32 & Petrox \\
\hline & 33 & Marsh \\
\hline & 34 & Isla de Pascua \\
\hline \multirow{5}{*}{ Ecuador } & 35 & Guayaquil \\
\hline & 36 & Riobamba \\
\hline & 37 & Salinas \\
\hline & 38 & Esmeraldas \\
\hline & 39 & San Cristóbal \\
\hline \multirow{4}{*}{ Mexico } & 48 & México \\
\hline & 49 & Cuernavaca \\
\hline & 50 & Potosí \\
\hline & 51 & Acapulco \\
\hline \multirow{3}{*}{ Panama } & 52 & Panamá \\
\hline & 53 & Colón \\
\hline & 54 & Veraguas \\
\hline
\end{tabular}

TABle 2: Continued.

\begin{tabular}{|c|c|c|}
\hline Country & Code & Test site \\
\hline \multirow{6}{*}{ Peru } & 55 & Piura \\
\hline & 56 & Villa Salvador \\
\hline & 57 & San Borja \\
\hline & 58 & Arequipa \\
\hline & 59 & Cuzco \\
\hline & 60 & Pucallpa \\
\hline \multirow{3}{*}{ Portugal } & 62 & Leixões \\
\hline & 63 & Sines \\
\hline & 64 & Pego \\
\hline \multirow{8}{*}{ Spain } & 40 & León \\
\hline & 41 & El Pardo \\
\hline & 42 & Barcelona, S \\
\hline & 43 & Tortosa \\
\hline & 44 & Granada \\
\hline & 45 & Lagoas \\
\hline & 46 & Labastida \\
\hline & 47 & Artíes \\
\hline \multirow{5}{*}{ Uruguay } & 65 & Trinidad \\
\hline & 66 & Prado \\
\hline & 67 & Melo \\
\hline & 68 & Artigas \\
\hline & 69 & Punta del Este \\
\hline \multirow{6}{*}{ Venezuela } & 70 & El Tablazo \\
\hline & 71 & Punto Fijo \\
\hline & 72 & Coro \\
\hline & 73 & Matanzas \\
\hline & 74 & Barcelona, V \\
\hline & 75 & Puerto Cabello \\
\hline
\end{tabular}

are short of atmospheres with only $\mathrm{SO}_{2}$ pollution or mixed high contents of both pollutants.

\subsection{Atmospheric Corrosion of Mild Steel}

3.1.1. Mechanisms [27]. According to Kucera and Mattsson [28], two general stages may be distinguished in the atmospheric corrosion of iron: initiation and propagation.

Initiation. In a dry, clean atmosphere the steel surface becomes coated with a $20-50 \AA$ thick oxide film that practically prevents further oxidation.

The initiation of corrosion on a clean metal surface in nonpolluted atmospheres is a very slow process, even in atmospheres saturated with water vapour. In this case, initiation may occur at surface inclusions such as MnS, which dissolve when the surface becomes wet $[29,30]$. Another important factor for the initiation of corrosion is the presence of solid particles on the surface [31].

During the initiation period, anodic spots surrounded by cathodic areas are formed. 
TABLE 3: Classification of MICAT test sites according to ISO 9223 [24].

\begin{tabular}{|c|c|c|c|}
\hline \multirow{2}{*}{ Type of atmosphere } & \multirow{2}{*}{ Denomination (ISO 9223) [24] } & \multicolumn{2}{|c|}{ Deposition rate } \\
\hline & & $\mathrm{Cl}^{-}\left(\mathrm{mg} \cdot \mathrm{m}^{-2} \cdot \mathrm{d}^{-1}\right)$ & $\mathrm{SO}_{2}\left(\mathrm{mg} \cdot \mathrm{m}^{-2} \cdot \mathrm{d}^{-1}\right)$ \\
\hline Rural atmospheres & $\mathrm{S}_{0} \mathrm{P}_{0}$ & $\mathrm{~S} \leq 3$ & $\mathrm{P} \leq 10$ \\
\hline \multirow{2}{*}{ Urban and industrial atmospheres } & $\mathrm{S}_{0} \mathrm{P}_{1}$ & $\mathrm{~S} \leq 3$ & $10<\mathrm{P} \leq 35$ \\
\hline & $\mathrm{S}_{0} \mathrm{P}_{2}$ & $\mathrm{~S} \leq 3$ & $35<\mathrm{P} \leq 80$ \\
\hline \multirow{3}{*}{ Marine atmospheres* } & $\mathrm{S}_{1} \mathrm{P}_{0}$ & $3<\mathrm{S} \leq 60$ & $\mathrm{P} \leq 10$ \\
\hline & $\mathrm{S}_{2} \mathrm{P}_{0}$ & $60<\mathrm{S} \leq 300$ & $\mathrm{P} \leq 10$ \\
\hline & $\mathrm{S}_{3} \mathrm{P}_{0}$ & $300<\mathrm{S} \leq 1500$ & $\mathrm{P} \leq 10$ \\
\hline \multirow{4}{*}{ Mixed atmospheres } & $\mathrm{S}_{1} \mathrm{P}_{1}$ & $3<\mathrm{S} \leq 60$ & $10<\mathrm{P} \leq 35$ \\
\hline & $\mathrm{S}_{1} \mathrm{P}_{2}$ & $3<\mathrm{S} \leq 60$ & $35<\mathrm{P} \leq 80$ \\
\hline & $\mathrm{S}_{2} \mathrm{P}_{1}$ & $60<\mathrm{S} \leq 300$ & $10<\mathrm{P} \leq 35$ \\
\hline & $\mathrm{S}_{2} \mathrm{P}_{2}$ & $60<\mathrm{S} \leq 300$ & $35<\mathrm{P} \leq 80$ \\
\hline
\end{tabular}

*Due to the singular climatic characteristic of the marine Antarctic test sites, they have been considered as a separate group, whose results have been already published [16].

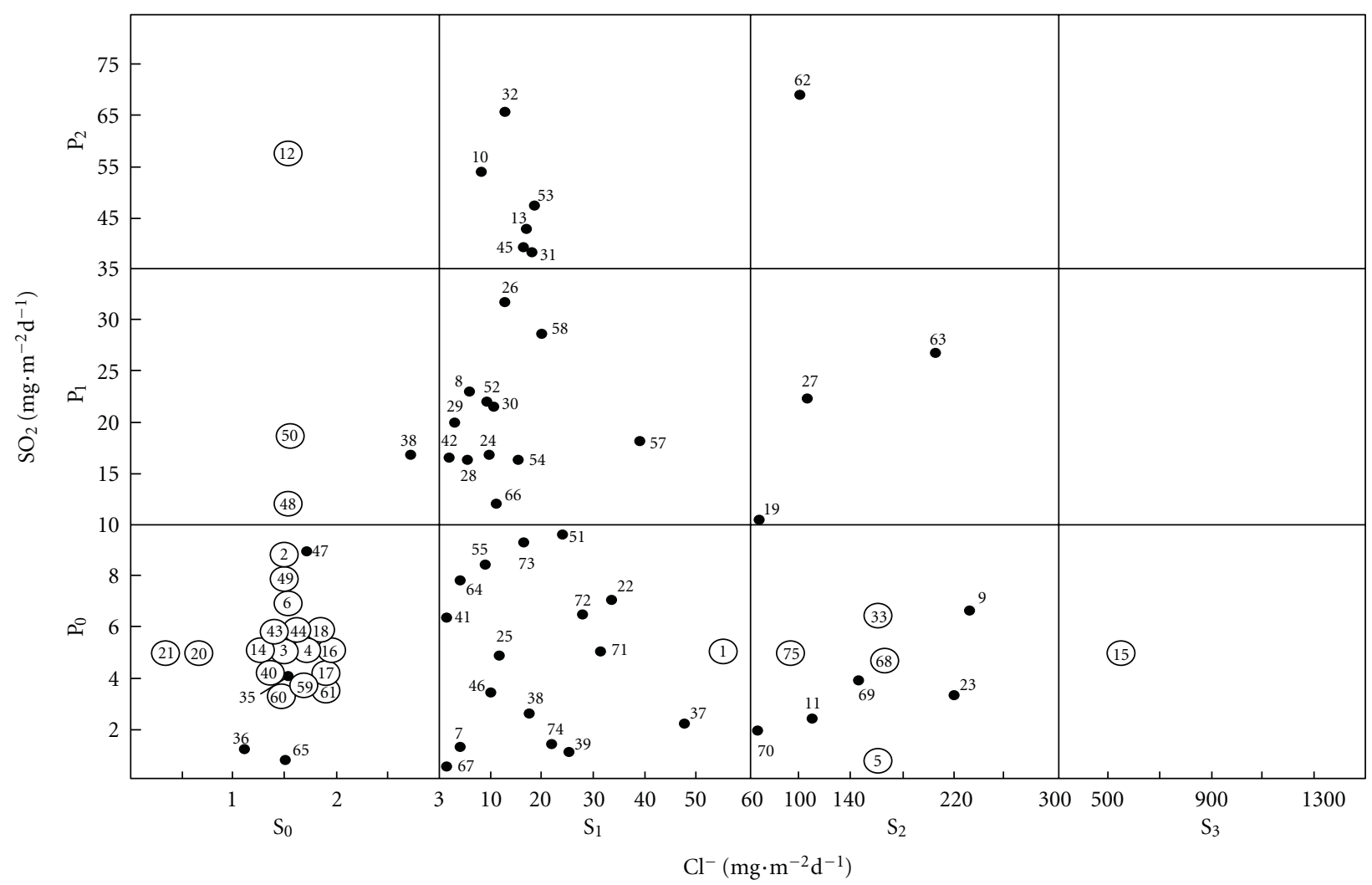

Figure 2: Classification of the test sites, according to ISO 9223 [24] and based on the $\mathrm{SO}_{2}$ and $\mathrm{Cl}^{-}$deposition rates (average of the first three years of exposure in the atmospheres). The test sites where the deposition rates have been estimated are surrounded with a circle.

Propagation. In the presence of an electrolyte film on the metal surface, conditions are created for propagation of the corrosion process.

The following equations may in principle describe the reactions taking place in the corrosion cells [28],

At the Anode:

$$
\mathrm{Fe} \longrightarrow \mathrm{Fe}^{2+}+2 \mathrm{e}^{-}
$$

At the Cathode. The main cathodic reaction is considered to be reduction of oxygen dissolved in the electrolyte film:

$$
\frac{1}{2} \mathrm{O}_{2}+\mathrm{H}_{2} \mathrm{O}+2 \mathrm{e}^{-} \longrightarrow 2 \mathrm{OH}^{-}
$$

This process causes a local increase in $\mathrm{pH}$ at the cathodes and promotes the precipitation of corrosion products at some distance from the anodes. 
Electrochemical studies by Stratmann and Müller [32] showed for the first time that oxygen is reduced within the oxide layer and not at the metal/electrolyte interface.

As soon as ferric corrosion products have been formed, another cathodic process may take place:

$$
\mathrm{Fe}^{3+}+\mathrm{e}^{-} \longrightarrow \mathrm{Fe}^{2+}
$$

Evans [33] developed an electrochemical model to explain the observed influence of changing wetness on the atmospheric corrosion of iron. He postulated that in periods of high water content within the porous structure of the rust, the anodic dissolution of iron is balanced by the cathodic reduction of $\mathrm{Fe}(\mathrm{III})$ oxides in the rust layer

$$
\mathrm{Fe}^{2+}+8 \mathrm{FeOOH}+2 \mathrm{e}^{-} \longrightarrow 3 \mathrm{Fe}_{3} \mathrm{O}_{4} \text { (unstable) }+4 \mathrm{H}_{2} \mathrm{O}
$$

The consensus in the early 1970s was that the main products of rust formed on mild steels in atmospheric corrosion were $\alpha$-FeOOH, $\gamma$ - $\mathrm{FeOOH}, \mathrm{Fe}_{3} \mathrm{O}_{4}$, and $\mathrm{X}$-ray amorphous matter. However, the mechanism of the formation of $\alpha-\mathrm{FeOOH}, \gamma$ $\mathrm{FeOOH}$, and amorphous matter in atmospheric rusting was not completely understood. In particular, the composition of amorphous matter remains undetermined.

Misawa et al. [34] characterised X-ray amorphous matter as amorphous ferric oxyhydroxide $\mathrm{FeO}_{x}(\mathrm{OH})_{3-2 x}$ by XRD and IRS, formulating the following mechanism of atmospheric rusting.

(a) Rusting starts with the formation of $\gamma$-FeOOH in a neutral to slightly acidic solution. In the first stage of rusting the aerial oxidation of ferrous ions, dissolved from the steel into a slightly acidic thin water layer formed by rain on the steel surface, leads to the precipitation of $\gamma$-FeOOH. Fine weather accelerates the precipitation and crystallisation of $\gamma$ FeOOH by drying,

$$
\begin{aligned}
\mathrm{Fe} & \stackrel{\text { dissolution }}{\longrightarrow} \mathrm{Fe}^{2+} \stackrel{\text { hydrolysis }}{\longrightarrow} \mathrm{FeOH}^{+} \\
\stackrel{\text { oxidation and precipitation }}{\longrightarrow} & \gamma \text { - } \mathrm{FeOOH}
\end{aligned}
$$

(b) The $\gamma$-FeOOH content is higher in inner rust layers than in outer layers, which contain large amounts of amorphous ferric oxyhydroxide and $\alpha$-FeOOH. This suggests that $\gamma$-FeOOH is formed on the steel surface and transformed to amorphous ferric oxyhydroxide and $\alpha-\mathrm{FeOOH}$ from the outer part upon atmospheric rusting as follows.

It is known that fresh rain dissolving impurities including $\mathrm{SO}_{2}$ in the atmosphere often shows a low $\mathrm{pH}$ value, such as $\mathrm{pH}$ 4. Such a low $\mathrm{pH}$ water layer dissolves $\gamma$-FeOOH and results in the precipitation of amorphous ferric oxyhydroxide with drying. The amorphous ferric oxyhydroxide transforms to $\alpha$-FeOOH by deprotonation using hydroxyl ions provided by the rain,

$$
\gamma \text {-FeOOH } \stackrel{\text { Dissolution and precipitation }}{\longrightarrow} \begin{gathered}
\mathrm{FeO}_{x}(\mathrm{OH})_{3-2 x} \\
\text { Amorphous ferric oxyhydroxide }
\end{gathered}
$$

$\stackrel{\text { Solid state transformation }}{\longrightarrow} \alpha$-FeOOH
The wet-dry cycle accelerates these rusting process, especially precipitation and transformation with deprotonation and dehydration.

Stratmann et al. [35], in an electrochemical study of phase transitions in rust layers, experimentally showed that the oxidation of $\mathrm{Fe}_{3} \mathrm{O}_{4}$ to $\gamma$ - $\mathrm{FeOOH}$ (reaction (7)), as proposed by Evans [33, 36] and Evans and Taylor [37], was not possible,

$$
3 \mathrm{Fe}_{3} \mathrm{O}_{4}+\frac{3}{4} \mathrm{O}_{2}+\frac{9}{2} \mathrm{H}_{2} \mathrm{O} \longrightarrow 9 \mathrm{FeOOH}
$$

Thus, in 1987 Stratmann et al. [35] proposed dividing the atmospheric corrosion mechanism of pure iron into the following three stages.

Stage 1: Wetting of the Dry Surface. As proposed by Evans $[33,36]$ and Evans and Taylor [37], a corrosion cell starts where the anodic dissolution of iron is balanced by the cathodic reduction of $\mathrm{Fe}(\mathrm{III})$ in the rust layer

$$
\begin{aligned}
& 2 \gamma-\mathrm{FeOOH}+2 \mathrm{H}^{+}+2 \mathrm{e} \longrightarrow 2 \mathrm{Fe} \cdot \mathrm{OH} \cdot \mathrm{OH} \\
& \text { (reduced surface layer on } \mathrm{FeOOH} \text { crystals) }
\end{aligned}
$$

During this stage the cathodic $\mathrm{O}_{2}$ reduction reaction is very slow compared to anodic iron dissolution. The metal dissolution rate is high, but the amount of dissolved iron is restricted to the amount of reducible $\mathrm{FeOOH}$ in the rust layer [38].

Stage 2: Wet Surface. Once the reducible FeOOH has been used up, the $\mathrm{O}_{2}$ reduction reaction becomes the cathodic reaction as in (2).

The metal dissolution rate is determined by the diffusion limited current density of the $\mathrm{O}_{2}$ reduction reaction on the pore surfaces. Because the pores in the rust layer are filled with electrolyte, the corrosion rate is quite slow during stage 2 , as the diffusion rate is lower in the electrolyte than in the gas phase.

Electrochemical studies by Stratmann and Müller [32] showed for the first time that oxygen is reduced within the oxide scale and not at the metal/electrolyte interface. This implies that the electronic structure of the oxides will strongly influence the reduction of oxygen and therefore also the corrosion rate. The atmospheric corrosion rate is determined for thin films by the electronic properties of the rust layer, and the corrosion rate immediately decreases as the oxides are reoxidised [39].

Stage 3: Drying-Out of the Surface. During drying-out, the rate of the diffusion limited $\mathrm{O}_{2}$ reduction reaction is extremely fast due to thinning of the electrolyte film on the inner surface of the rust layer. Accordingly, the corrosion rate is very high, $\mathrm{O}_{2}$ reduction again being the cathodic reaction.

In addition to this, $\mathrm{O}_{2}$ can reoxidise the reduced $\mathrm{Fe}^{2+}$ formed in stage 1

$$
2 \mathrm{Fe} \cdot \mathrm{OH} \cdot \mathrm{OH}+2 \mathrm{O}_{2} \longrightarrow 2 \mathrm{FeOOH}+\mathrm{H}_{2} \mathrm{O}
$$

As a consequence of the high corrosion rate, stage 3 seems to dominate the metal loss during the whole wet-dry cycle. 
In the third stage, the reduced layer of $\gamma$-FeOOH and the other ferrous species are reoxidised by oxygen, leading to the formation of goethite and the regeneration of lepidocrocite. The electrolyte film is used up, stopping the corrosion process completely. It is during this final stage that the rust layer composition changes, leading to a different intensity in the corrosion process for the next wet-dry cycle.

Misawa [34] notes that the main constituent of rust in a rural (unpolluted) atmosphere is $\gamma-\mathrm{FeOOH}$, while in an atmosphere containing $\mathrm{SO}_{2}$ a large amount of $\alpha$-FeOOH is detected.

The atmospheric corrosion process is stimulated by $\mathrm{SO}_{2}$, which is adsorbed and oxidised in the rust layer to $\mathrm{SO}_{4}{ }^{2-}$. In the corrosion cells, sulphate accumulates at the anodes and thus creates so-called sulphate nests in the rust, which were first described by Schwarz [40].

When the surface becomes wetted by rain, dew, or moisture adsorption, the sulphate nests in combination with the surrounding area form corrosion cells. The electrolyte is mostly very concentrated and has low water activity. Anodes are located inside the sulphate nests.

The sulphate nest becomes enclosed within a semipermeable membrane of hydroxide formed through oxidative hydrolysis of the iron ions. Diffusion causes transfer of sulfate ions into the nest. This will stabilise the existence of the nest.

Hydrolysis of the ferrous sulphate formed in these nests controls their propagation. The osmotic pressure can cause them to burst, thus increasing the corrosion rate. The nests are covered by a membrane containing $\mathrm{FeOOH}$. The higher the amorphous $\mathrm{FeOOH}$ content, the greater the stability of this membrane and the more unlikely it is to burst due to the effect of osmotic pressure and the repeated wetting and drying of the rust layer.

In atmospheres polluted with chlorides the corrosion of carbon steel proceeds in local cells which resemble the sulphate nests mentioned above [41]. They may arise around chloride particles deposited on the surface, where the concentrated chloride solution locally destroys the $\mathrm{FeOOH}$ passivating film. In the anodic areas so formed, the chlorides are concentrated by migration while the rust-coated surrounding area acts as a cathode. However, unlike in the case of atmospheres polluted with $\mathrm{SO}_{2}$, nests are not formed. No amorphous oxide/hydroxide membrane is formed. It is fairly common to find iron chlorides among the iron corrosion products, which tend to accumulate at the steel/rust interface by migration.

In marine atmospheres, in addition to $\gamma$ - $\mathrm{FeOOH}$ and $\alpha$ $\mathrm{FeOOH}$, akaganeite $(\beta$-FeOOH$)$ and magnetite $\left(\mathrm{Fe}_{3} \mathrm{O}_{4}\right)$ are also formed. The latter species tends to be concentrated in the innermost zones of the rust layer, where it is hardest for oxygen to reach. In contrast, akaganeite forms in the most superficial zones of the rust layer.

Sea chlorides from natural airborne salinity together with $\mathrm{SO}_{2}$ play an important role in determining the magnitude of atmospheric steel corrosion. However, the scientific literature contains relatively little information on atmospheric corrosion in this type of mixed atmospheres.

The diversity of industrial environments, with the possible presence of other pollutants that may influence the

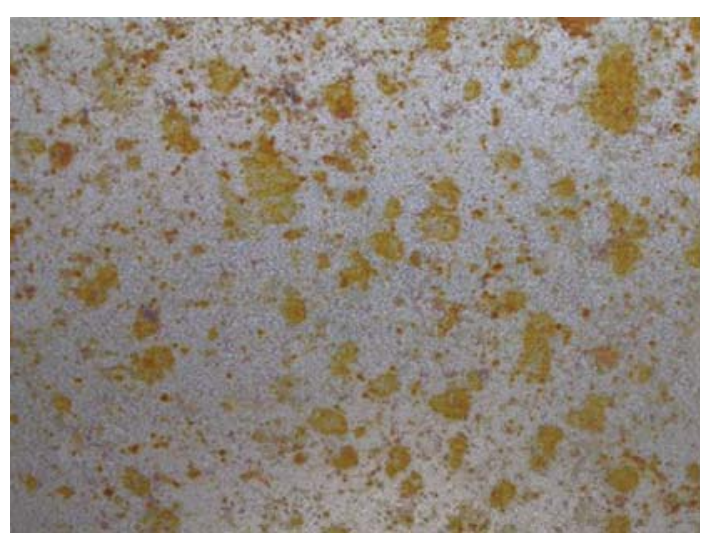

Figure 3: Appearance of the mild steel surface after one year of outdoor exposure in Cuzco.

corrosion process, has given rise to several papers on the effect of both pollutants ( $\mathrm{SO}_{2}$ and chlorides), acting together. Thus, Ericsson [42] speaks of a synergic effect of the combined influence of $\mathrm{SO}_{2}$ and sodium chloride while others speak of a competitive absorption effect [43].

3.2. Main Results Obtained in the MICAT Project. Table 4 displays information obtained in the MICAT project $[6,7]$ and Table 5 gives a list of the main corrosion products identified.

There follows a summary of mild steel behaviour in the MICAT project testing station network covering different types of atmospheres according to ISO 9223 (Table 3).

\section{Unpolluted Atmospheres $\left(S_{0} P_{0}\right)$ :}

(i) $\mathrm{S}_{0} \mathrm{P}_{0}$ rural atmospheres, with very low chloride and $\mathrm{SO}_{2}$ pollution, showed significantly different time of wetness (TOW) and environmental characteristics, such as soil particulate pollution and background pollution. As a consequence of these differences, a relatively wide range of steel corrosion rates could be observed, from 1.4 to $28.2 \mu \mathrm{m} \cdot \mathrm{y}^{-1}$, after one year of exposure. The steel corrosion product layers were constituted by lepidocrocite or lepidocrocite and goethite.

(ii) An extremely low first-year corrosion rate of steel (Ave. $1.4 \mu \mathrm{m} \cdot \mathrm{y}^{-1}$ ) in the atmosphere of Cuzco (Peru) was found, perhaps the lowest ever reported in the literature [44].

The low atmospheric corrosion of steel in this Peruvian city was evident by inspecting the surface of steel exposed to the atmosphere for one year (Figure 3). The surface was not fully rusted and only showed scattered corrosion spots. This suggests that the metal surface does not go beyond the early steps of the atmospheric corrosion process, where the attack is limited to a few anodic areas while the rest of the metal surface remains unaltered.

Different hypotheses were put forward to try to explain this singular behaviour: very short TOW, steel composition, 
TABLE 4: MICAT test sites characteristics. Data for mild steel.

\begin{tabular}{|c|c|c|c|c|c|c|c|c|}
\hline \multirow[t]{2}{*}{$\begin{array}{l}\text { Type of } \\
\text { atmosphere } \\
\text { (Table } 3 \text { ) }\end{array}$} & \multirow[t]{2}{*}{$\begin{array}{c}\text { Id. } \\
\text { (Table 2) }\end{array}$} & \multirow[t]{2}{*}{ Name } & \multicolumn{2}{|c|}{$\begin{array}{l}\text { Deposition rate } \\
\left(\mathrm{mg} \cdot \mathrm{m}^{-2} \cdot \mathrm{d}^{-1}\right)\end{array}$} & \multirow[t]{2}{*}{$\begin{array}{l}\text { Time of } \\
\text { wetness } \\
\text { (TOW) }\end{array}$} & \multirow[t]{2}{*}{$\begin{array}{l}\text { 1st-year } \\
\text { corrosion } \\
\text { rate }(\mu \mathrm{m})\end{array}$} & \multirow[t]{2}{*}{$\begin{array}{c}\text { Atmospheric } \\
\text { corrosivity } \\
\text { (ISO 9223) } \\
\text { [24] }\end{array}$} & \multirow[t]{2}{*}{$\begin{array}{l}\text { Corrosion products } \\
\text { (see Table 5) }\end{array}$} \\
\hline & & & $\mathrm{Cl}^{-}$ & $\mathrm{SO}_{2}$ & & & & \\
\hline \multirow{19}{*}{$\mathrm{S}_{0} \mathrm{P}_{0}$} & 60 & Cuzco & $(*)$ & $(*)$ & $\tau_{4}$ & 1,4 & $\mathrm{C} 2$ & - \\
\hline & 47 & Artíes & 1,7 & 9,0 & $\tau_{3}$ & 3,9 & $\mathrm{C} 2$ & $\mathrm{~L}, \mathrm{G}$ \\
\hline & 4 & San Juan & $(*)$ & $(*)$ & $\tau_{3}$ & 4,9 & $\mathrm{C} 2$ & - \\
\hline & 3 & Iguazú & $(*)$ & $(*)$ & $\tau_{5}$ & 5,7 & $\mathrm{C} 2$ & $\mathrm{~L}$ \\
\hline & 65 & Trinidad & 1,5 & 0,7 & $\tau_{4}$ & 6,7 & $\mathrm{C} 2$ & - \\
\hline & 36 & Riobamba & 1,1 & 1,2 & $\tau_{4}$ & 8,4 & $\mathrm{C} 2$ & $\mathrm{~L}$ \\
\hline & 44 & Granada & $(*)$ & 6,2 & $\tau_{3}$ & 8,5 & $\mathrm{C} 2$ & $\mathrm{~L}, \mathrm{G}$ \\
\hline & 16 & Brasilia & $(*)$ & $(*)$ & $\tau_{4}$ & 12,9 & $\mathrm{C} 2$ & $\mathrm{~L}$ \\
\hline & 49 & Cuernavaca & $(*)$ & 7,9 & $\tau_{3}$ & 13,4 & $\mathrm{C} 2$ & $L, G$ \\
\hline & 61 & Pucallpa & $(*)$ & $(*)$ & $\tau_{5}$ & 14,3 & $\mathrm{C} 2$ & $\mathrm{~L}, \mathrm{G}$ \\
\hline & 2 & V. Martelli & $(*)$ & 9,0 & $\tau_{4}$ & 14,7 & $\mathrm{C} 2$ & $\mathrm{~L}$ \\
\hline & 59 & Arequipa & $(*)$ & $(*)$ & $\tau_{2}$ & 15,4 & $\mathrm{C} 2$ & $\mathrm{~L}$ \\
\hline & 20 & San Pedro & $(*)$ & 0,6 & $\tau_{5}$ & 17,0 & $\mathrm{C} 2$ & $L, G$ \\
\hline & 14 & Belem & $(*)$ & $(*)$ & $\tau_{5}$ & 19,4 & $\mathrm{C} 2$ & $\mathrm{~L}, \mathrm{G}$ \\
\hline & 21 & Cotové & $(*)$ & 0,3 & $\tau_{4}$ & 19,6 & $\mathrm{C} 2$ & $\mathrm{~L}, \mathrm{G}$ \\
\hline & 43 & Tortosa & $(*)$ & 5,3 & $\tau_{4}$ & 20,2 & $\mathrm{C} 2$ & $\mathrm{~L}, \mathrm{G}$ \\
\hline & 40 & León & $(*)$ & $(*)$ & $\tau_{3}$ & 20,8 & $\mathrm{C} 2$ & $L, G$ \\
\hline & 35 & Guayaquil & 1,5 & 3,0 & $\tau_{4}$ & 22,6 & $\mathrm{C} 2$ & $\mathrm{~L}$ \\
\hline & 6 & La Plata & $(*)$ & 6,9 & $\tau_{4}$ & 28,1 & $\mathrm{C} 3$ & - \\
\hline \multirow{2}{*}{$\mathrm{S}_{0} \mathrm{P}_{1}$} & 48 & México & $(*)$ & 13.6 & $\tau_{3}$ & 9.7 & $\mathrm{C} 2$ & - \\
\hline & 50 & S. L. Potosí & $(*)$ & 18.9 & $\tau_{3}$ & 31.1 & $\mathrm{C} 3$ & - \\
\hline $\mathrm{S}_{0} \mathrm{P}_{2}$ & 12 & São Paulo & $(*)$ & 57.8 & $\tau_{5}$ & 20.6 & $\mathrm{C} 2$ & $\mathrm{~L}, \mathrm{G}$ \\
\hline \multirow{17}{*}{$\mathrm{S}_{1} \mathrm{P}_{0}$} & 67 & Melo & 3,8 & 0,7 & $\tau_{5}$ & 12,8 & $\mathrm{C} 2$ & - \\
\hline & 41 & El Pardo & 3,9 & 6,4 & $\tau_{4}$ & 11,3 & $\mathrm{C} 2$ & $\mathrm{~L}, \mathrm{G}$ \\
\hline & 7 & Caratinga & 5,8 & 1,3 & $\tau_{4}$ & 11,1 & $\mathrm{C} 2$ & $\mathrm{~L}, \mathrm{G}, \mathrm{Mg}$ \\
\hline & 64 & Pego & 6,0 & 7,9 & $\tau_{4}$ & 28,5 & $\mathrm{C} 3$ & $\mathrm{~L}, \mathrm{G}$ \\
\hline & 55 & Chiriquí & 8,7 & 8,2 & $\tau_{4}$ & 23,0 & $\mathrm{C} 2$ & $\mathrm{G}, \mathrm{L}, \mathrm{Mg}$ \\
\hline & 46 & Labastida & 9,8 & 3,6 & $\tau_{4}$ & 15,0 & $\mathrm{C} 2$ & $\mathrm{~L}, \mathrm{G}$ \\
\hline & 25 & Sabanilla & 11,3 & 4,9 & $\tau_{5}$ & 16,6 & $\mathrm{C} 2$ & $L, G$ \\
\hline & 73 & Matanzas & 15,9 & 9,3 & $\tau_{4}$ & 23,0 & $\mathrm{C} 2$ & - \\
\hline & 24 & Arenal & 16,7 & 9,2 & $\tau_{5}$ & 69,3 & $\mathrm{C} 4$ & $\mathrm{~L}, \mathrm{G}, \mathrm{M}$ \\
\hline & 74 & Barcelona, $\mathrm{V}$ & 21,8 & 1,5 & $\tau_{4}$ & 18,5 & $\mathrm{C} 2$ & $\mathrm{~L}, \mathrm{G}$ \\
\hline & 51 & Acapulco & 23,8 & 9,6 & $\tau_{4}$ & 22,1 & $\mathrm{C} 2$ & $\mathrm{~L}, \mathrm{G}, \mathrm{M}$ \\
\hline & 39 & S. Cristóbal & 25,0 & 1,1 & - & 34,5 & $\mathrm{C} 3$ & - \\
\hline & 72 & Coro & 27,5 & 6,5 & $\tau_{4}$ & 14,8 & $\mathrm{C} 2$ & - \\
\hline & 71 & Punto Fijo & 31,0 & 5,0 & $\tau_{4}$ & 21,4 & $\mathrm{C} 2$ & $\mathrm{~L}, \mathrm{G}$ \\
\hline & 22 & Puntarenas & 33,4 & 7,1 & $\tau_{4}$ & 61,6 & $\mathrm{C} 4$ & $\mathrm{~L}, \mathrm{G}, \mathrm{Mg}$ \\
\hline & 37 & Salinas & 47,3 & 2,3 & $\tau_{4}$ & 55,4 & $\mathrm{C} 4$ & - \\
\hline & 1 & Camet & 55,1 & $(*)$ & $\tau_{5}$ & 49,5 & $\mathrm{C} 3$ & $\mathrm{~L}, \mathrm{G}$ \\
\hline \multirow{6}{*}{$\mathrm{S}_{2} \mathrm{P}_{0}$} & 70 & El Tablazo & 63,3 & 6,0 & $\tau_{4}$ & 29,3 & $\mathrm{C} 3$ & $L, G$ \\
\hline & 75 & P. Cabello & - & $(*)$ & $\tau_{5}$ & 37,3 & C3 & L, G, A \\
\hline & 11 & Ubatuba & 113 & 2,6 & $\tau_{4}$ & 302,0 & $\mathrm{C} 5$ & $\mathrm{~L}, \mathrm{G}, \mathrm{A}, \mathrm{M}$ \\
\hline & 69 & P. del Este & 144 & 4,0 & $\tau_{4}$ & 53,0 & $\mathrm{C} 4$ & - \\
\hline & 23 & Limón & 220 & 3,5 & $\tau_{5}$ & 371,5 & $>\mathrm{C} 5$ & $\mathrm{~L}, \mathrm{G}, \mathrm{M}$ \\
\hline & 9 & A. do Cabo & 229 & 6,7 & $\tau_{4}$ & 165,4 & $\mathrm{C} 5$ & $\mathrm{G}, \mathrm{M}, \mathrm{L}, \mathrm{Mg}$ \\
\hline $\mathrm{S}_{3} \mathrm{P}_{0}$ & 15 & Fortaleza & $>300$ & $(*)$ & $\tau_{4}$ & 118.3 & $\mathrm{C} 5$ & - \\
\hline
\end{tabular}


Table 4: Continued.

\begin{tabular}{|c|c|c|c|c|c|c|c|c|}
\hline \multirow[t]{2}{*}{$\begin{array}{l}\text { Type of } \\
\text { atmosphere } \\
\text { (Table 3) }\end{array}$} & \multirow[t]{2}{*}{$\begin{array}{c}\text { Id. } \\
\text { (Table 2) }\end{array}$} & \multirow[t]{2}{*}{ Name } & \multicolumn{2}{|c|}{$\begin{array}{l}\text { Deposition rate } \\
\left(\mathrm{mg} \cdot \mathrm{m}^{-2} \cdot \mathrm{d}^{-1}\right)\end{array}$} & \multirow[t]{2}{*}{$\begin{array}{l}\text { Time of } \\
\text { wetness } \\
\text { (TOW) }\end{array}$} & \multirow[t]{2}{*}{$\begin{array}{l}\text { 1st-year } \\
\text { corrosion } \\
\text { rate }(\mu \mathrm{m})\end{array}$} & \multirow[t]{2}{*}{$\begin{array}{c}\text { Atmospheric } \\
\text { corrosivity } \\
\text { (ISO 9223) } \\
\text { [24] }\end{array}$} & \multirow[t]{2}{*}{$\begin{array}{l}\text { Corrosion products } \\
\qquad \text { (see Table 5) }\end{array}$} \\
\hline & & & $\mathrm{Cl}^{-}$ & $\mathrm{SO}_{2}$ & & & & \\
\hline \multirow{11}{*}{$\mathrm{S}_{1} \mathrm{P}_{1}$} & 42 & Barcelona, S & 4,4 & 16,7 & $\tau_{3}$ & 17,4 & $\mathrm{C} 2$ & L, G \\
\hline & 54 & Veraguas & 14,8 & 16,5 & $\tau_{4}$ & 20,0 & $\mathrm{C} 2$ & $\mathrm{~L}, \mathrm{G}, \mathrm{Mg}$ \\
\hline & 52 & Panamá & 9,8 & 21,7 & $\tau_{4}$ & 27,6 & C3 & $\mathrm{L}, \mathrm{G}, \mathrm{Mg}$ \\
\hline & 26 & $\mathrm{Ciq}$ & 12,0 & 31,6 & $\tau_{4}$ & 30,4 & C3 & $\mathrm{G}, \mathrm{L}$ \\
\hline & 58 & San Borja & 20,0 & 29,0 & $\tau_{5}$ & 30,8 & $\mathrm{C} 3$ & $\mathrm{~L}, \mathrm{G}$ \\
\hline & 66 & Prado & 10,8 & 12,1 & $\tau_{4}$ & 33,3 & $\mathrm{C} 3$ & - \\
\hline & 28 & Bauta & 6,4 & 16,4 & $\tau_{4}$ & 33,8 & $\mathrm{C} 3$ & $\mathrm{~L}, \mathrm{G}$ \\
\hline & 57 & V. Salvador & 38,0 & 18,0 & $\tau_{5}$ & 35,1 & C3 & $\mathrm{L}, \mathrm{M}$ \\
\hline & 30 & Valparaíso & 10,0 & 23,6 & $\tau_{5}$ & 35,5 & C3 & - \\
\hline & 29 & Cerrillos & 4,5 & 20,0 & $\tau_{4}$ & 36,3 & $\mathrm{C} 3$ & $\mathrm{~L}, \mathrm{G}$ \\
\hline & 8 & Ipatinga & 6,8 & 23,0 & $\tau_{4}$ & 49,4 & C3 & $\mathrm{L}, \mathrm{G}$ \\
\hline \multirow{5}{*}{$\mathrm{S}_{1} \mathrm{P}_{2}$} & 45 & Lagoas & 16,7 & 39,5 & $\tau_{4}$ & 28,2 & $\mathrm{C} 3$ & $\mathrm{~L}, \mathrm{G}$ \\
\hline & 53 & Colón & 16,8 & 47,4 & $\tau_{5}$ & 108,1 & C5 & $\mathrm{G}, \mathrm{L}$ \\
\hline & 13 & Río Janeiro & 16,4 & 43,5 & $\tau_{4}$ & 110,5 & C5 & $\mathrm{L}, \mathrm{G}$ \\
\hline & 10 & Cubatão & 8,1 & 54,5 & $\tau_{4}$ & 158,9 & $\mathrm{C} 5$ & $\mathrm{~L}, \mathrm{G}, \mathrm{M}$ \\
\hline & 32 & Petrox & 12,8 & 65,2 & $\tau_{5}$ & 167,2 & $\mathrm{C} 5$ & - \\
\hline \multirow{3}{*}{$\mathrm{S}_{2} \mathrm{P}_{1}$} & 19 & Isla Naval & 60,7 & 10,3 & $\tau_{5}$ & 33,5 & $\mathrm{C} 3$ & $\mathrm{~L}, \mathrm{G}, \mathrm{A}$ \\
\hline & 27 & Cojímar & 104 & 22,5 & $\tau_{4}$ & 193,2 & $\mathrm{C} 5$ & $\mathrm{M}, \mathrm{L}, \mathrm{G}$ \\
\hline & 63 & Sines & 203 & 27,0 & $\tau_{4}$ & 365,0 & $>\mathrm{C} 5$ & $\mathrm{~L}, \mathrm{G}, \mathrm{A}, \mathrm{M}, \mathrm{Mg}$ \\
\hline $\mathrm{S}_{2} \mathrm{P}_{2}$ & 62 & Leixões & 97,6 & 69,2 & $\tau_{4}$ & 72,4 & $\mathrm{C} 4$ & $\mathrm{~L}, \mathrm{G}, \mathrm{M}$ \\
\hline
\end{tabular}

$(*)$ apparently nonpolluted.

(一) not available.

TABLE 5: Steel corrosion products identified in the MICAT project.

\begin{tabular}{lcc}
\hline Code & Name & Composition \\
\hline & Hydroxides & \\
$\mathrm{L}$ & Lepidocrocite & $\gamma$-FeOOH \\
$\mathrm{G}$ & Goethite & $\alpha$-FeOOH \\
$\mathrm{A}$ & Akaganeite & $\beta$-FeOOH \\
& Oxides & \\
$\mathrm{M}$ & Magnetite & $\mathrm{Fe}_{3} \mathrm{O}_{4}$ \\
$\mathrm{Mg}$ & Maghemite & $\gamma-\mathrm{Fe}_{2} \mathrm{O}_{3}$ \\
\hline
\end{tabular}

and low atmospheric pollution. From the results obtained, it seems that the atmosphere of Cuzco is almost unpolluted, which may account for the extremely low corrosion rates found. Some authors $[45,46]$ suggest that the presence of strong oxidants such as hydrogen peroxide and ozone can favour the formation of a passivating layer over the steel surface, thereby inhibiting the atmospheric corrosion process. In this respect, the great height of Cuzco $(3219 \mathrm{~m})$ may account for increased amounts of ozone.

\section{$\mathrm{SO}_{2}$-Polluted Atmospheres $\left(S_{0} P_{1}, S_{0} P_{2}\right)$ :}

(i) The scarce data obtained in the MICAT project for steel samples exposed in urban atmospheres
$\left(\mathrm{SO}_{2} \leq 60 \mathrm{mg} \cdot \mathrm{m}^{-2} \cdot \mathrm{d}^{-1}\right.$ of $\left.\mathrm{SO}_{2}\right)$, only 3 test sites, yields results which are not significantly different to those obtained in rural atmospheres. However, it was confirmed by Mössbauer spectroscopy that the $\alpha$-FeOOH$/ \gamma$-FeOOH ratio increases when $\mathrm{SO}_{2}$ pollution increases.

Pure Marine Atmospheres $\left(S_{1} P_{0}, S_{2} P_{0}, S_{3} P_{0}\right)$ :

(i) In $\mathrm{S}_{1} \mathrm{P}_{0}$ marine atmospheres (low chloride deposition rates) mild steel presented corrosivity categories from C2 to C4, and the corrosion surface layer exhibited a morphology characterized by cotton balls of acicular iron corrosion products (Figure 4(a)). The relatively compact corrosion product layers were composed of lepidocrocite, goethite, and occasionally traces of maghemite and/or magnetite.

(ii) In $\mathrm{S}_{2} \mathrm{P}_{0}$ marine atmospheres, corrosion product layers exhibited more open structures (Figure 4(b)) and a greater tendency to flaking, showing higher corrosivity categories $(\mathrm{C} 3-\mathrm{C} 5)$. When $\mathrm{S}>60 \mathrm{mg} \cdot \mathrm{m}^{-2} \cdot \mathrm{d}^{-1}$ of $\mathrm{Cl}^{-}$and TOW $\geq \tau_{4}$, the presence of akaganeite $(\beta$ $\mathrm{FeOOH}$ ) can be seen among the corrosion products. The surface morphology of corrosion layers corresponds to generalized honeycomb structures. 

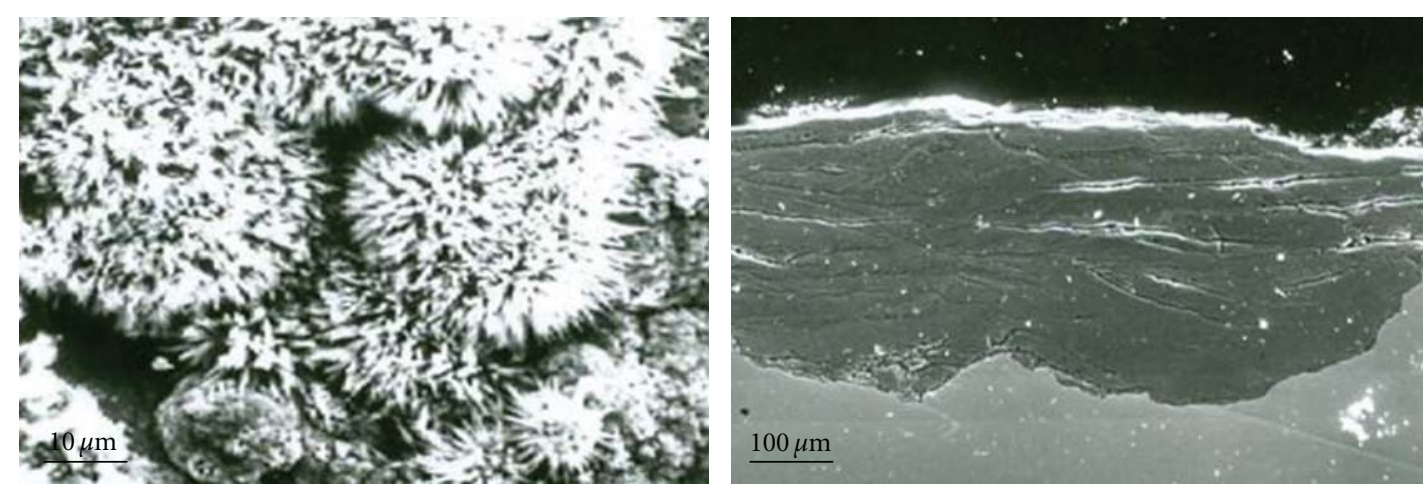

(a)
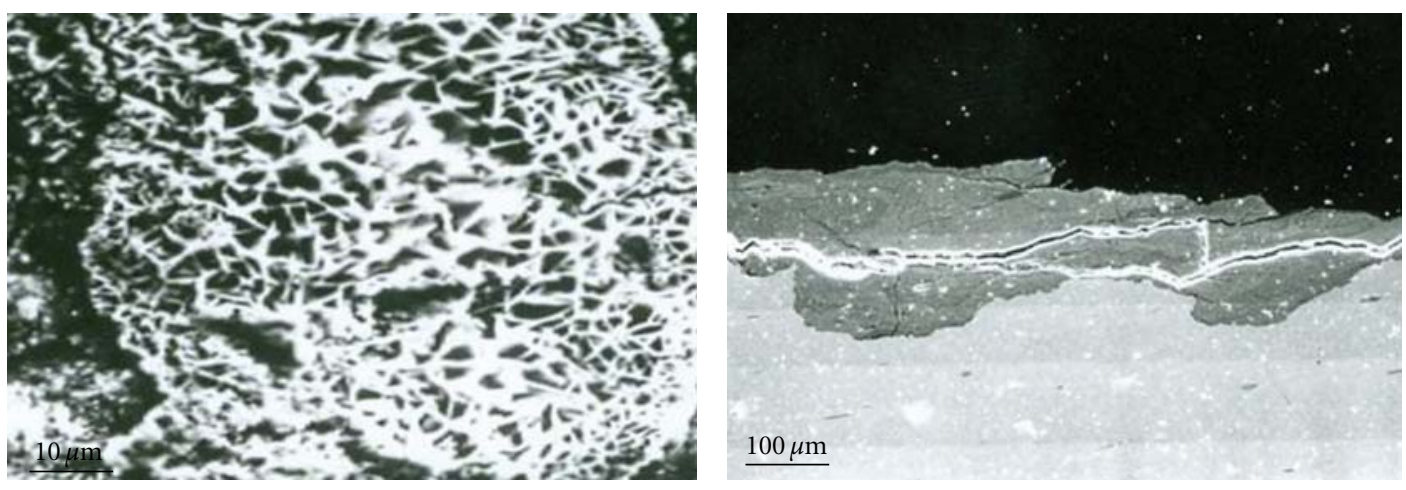

(b)

FIgURE 4: SEM micrographs of corrosion product layers formed on mild steel in pure marine atmospheres: (a) Puntarenas $\left(\mathrm{S}_{1} \mathrm{P}_{0}\right)$ and $(\mathrm{b})$ Arraial do Cabo $\left(\mathrm{S}_{2} \mathrm{P}_{0}\right)$.

Mixed Marine Atmospheres $\left(S_{1} P_{1}, S_{2} P_{2}, S_{2} P_{1}, S_{2} P_{2}\right)$ :

(i) They showed different corrosivity categories (from $\mathrm{C} 2$ to $>\mathrm{C} 5$ ), depending on their $\mathrm{SO}_{2}$ and $\mathrm{Cl}^{-}$pollution levels. Most of iron corrosion products were identified: L, G, A, M, Mg (Table 5).

(ii) The cracking effect in the corrosion product layer seems to increase with $\mathrm{SO}_{2}$ pollution and TOW while the contribution of chloride ions into the open structures seems to play a detrimental effect on atmospheric corrosion resistance.

\subsection{Atmospheric Corrosion of Zinc}

3.3.1. Mechanisms [47]. A prerequisite for atmospheric corrosion to occur is that a moisture layer be present on the zinc surface. This layer acts as a solvent for atmospheric constituents and a medium for electrochemical reactions. The atmospheric corrosion of zinc is influenced principally by the time of wetness and the presence of atmospheric constituents such as $\mathrm{CO}_{2}, \mathrm{SO}_{x}$, and $\mathrm{Cl}^{-}$. When the moisture layer evaporates, a film of corrosion products precipitates.

Unlike in the atmospheric corrosion of iron, the corrosion products formed on zinc include the respective characteristic anion of the environment where the metal is exposed: $\mathrm{CO}_{3}{ }^{2-}, \mathrm{SO}_{4}{ }^{2-}, \mathrm{Cl}^{-}$, and so forth, giving rise to different basic chemical compounds: carbonates, sulphates, chlorides, and so forth. Zinc exposed to the atmosphere is particularly sensitive to wetting and drying cycles, which are largely dependent on the climatology. These alternating periods have a considerable influence on certain characteristics of the corrosion products, such as their amount and compactness.

As other metals zinc corrodes in the atmosphere in a discontinuous process, electrochemical in nature, each time the metallic surface is wet. Quintana et al. [48] point out the importance of the temperature-humidity complex in the atmospheric corrosion of zinc. Both metal temperature and time of wetness influence the morphology of the corrosion products formed.

A $\mathrm{ZnO}$ (zincite) film is the first thin layer to form from the reaction of zinc with atmospheric oxygen [49]. According to Schikorr [50] these films have a relatively minor protective effect. In the presence of water, zincite is promptly transformed into hydroxides. Many studies agree that upon initial exposure zinc rapidly forms a thin film of zinc hydroxide. In continued exposure this film is transformed into various other atmospheric corrosion products [51].

Carbonates are formed as a result of the reaction of zinc hydroxide with atmospheric $\mathrm{CO}_{2}$. Although several compounds have been detected, the most common are $\mathrm{ZnCO}_{3}$ (smithsonite) and $\mathrm{Zn}_{5}\left(\mathrm{CO}_{3}\right)_{2}(\mathrm{OH})_{6}$ (hydrozincite). However, hydrozincite is sometimes difficult to detect by XRD.

$\mathrm{SO}_{2}$ concentration in the atmosphere is a major factor in controlling the rate of corrosion of zinc; the zinc corrosion film has been shown to strongly absorb $\mathrm{SO}_{2}$ during 


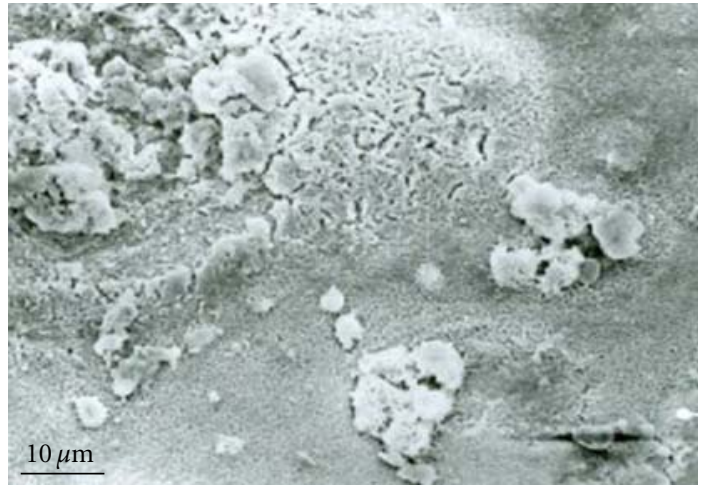

(a)

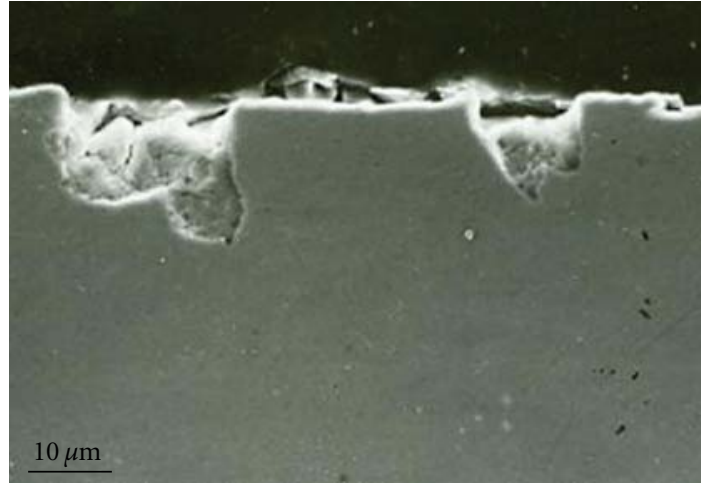

(b)

FIgURE 5: Morphology of corrosion product layers formed on zinc in unpolluted atmospheres: (a) Villa Martelli (surface view) and (b) La Plata (cross-section view).

dry deposition. Likewise, deposition of acidic condensates produces a fall in $\mathrm{pH}$ and the rate of zinc attack again increases [52]. There is an approximately linear relationship between zinc corrosion rate and sulphur dioxide concentration in the atmosphere [53]. In $\mathrm{SO}_{2}$-polluted atmospheres the formation of basic zinc sulphates and zinc hydroxysulfate takes place. Different compounds may be formed $\left[6 \mathrm{Zn}(\mathrm{OH})_{2} \cdot \mathrm{ZnSO}_{4} \cdot 4 \mathrm{H}_{2} \mathrm{O}\right], \quad\left[\mathrm{Zn}_{7}(\mathrm{OH})_{12} \cdot \mathrm{SO}_{4}\right.$. $\left.4 \mathrm{H}_{2} \mathrm{O}\right],\left[\mathrm{Zn}_{2}(\mathrm{OH})_{2} \cdot \mathrm{ZnSO}_{4}\right],\left[\mathrm{Zn}_{2}(\mathrm{OH})_{2} \mathrm{SO}_{4}\right], 3 \mathrm{Zn}(\mathrm{OH})_{2}$. $\left.\mathrm{ZnSO}_{4} \cdot 4 \mathrm{H}_{2} \mathrm{O}\right],\left[\mathrm{Zn}_{4}(\mathrm{OH})_{6} \mathrm{SO}_{4} \cdot 4 \mathrm{H}_{2} \mathrm{O}\right]$, and so forth, whose precipitation contributes [54] to the inhibition of the atmospheric corrosion of zinc. However, in this type of atmospheres the condensed moisture is acidic and corrodes zinc at a rapid rate. The corrosion products are dissolved and washed off by the acid rain.

Chloride in marine atmospheres also increases the atmospheric corrosion of zinc. There is also a linear relationship between the corrosion rate and salinity [55] in the atmosphere. In the case of pure marine atmospheres, the protective hydrozincite is attacked by chlorides, leading to its transformation into zinc hydroxychloride (simonkolleite). Basic chlorides are scarcely soluble and are not washed off by the rainwater, remaining in the layer of corrosion products.

When $\mathrm{SO}_{2}$ is also present in marine atmospheres, Svenson and Johansson [54] note that an inhibiting effect is sometimes observed due to the formation of sodium zinc chlorohydroxysulfate $\left[\mathrm{NaZn}_{4} \mathrm{Cl}(\mathrm{OH})_{6} \mathrm{SO}_{4} \cdot 6 \mathrm{H}_{2} \mathrm{O}\right]$ or zinc chlorohydroxysulfate $\left[\mathrm{Zn}_{4} \mathrm{Cl}_{2}(\mathrm{OH})_{4} \cdot \mathrm{SO}_{4} \cdot 5 \mathrm{H}_{2} \mathrm{O}\right]$.

3.3.2. Main Results Obtained in the MICAT Project. Table 6 displays information obtained in the MICAT project $[8,9]$ and Table 7 gives a list of the main corrosion products identified.

There follows an analysis of zinc behaviour in the MICAT project testing station network covering different types of atmospheres according to ISO 9223 (Table 3).

\section{Unpolluted Atmospheres $\left(S_{0} P_{0}\right)$ :}

(i) Zinc displays a wide range of first-year corrosion rate values: $0.11-3.30 \mu \mathrm{m} \cdot \mathrm{y}^{-1}$. (ii) Zincite $(\mathrm{ZnO})$ and hydrozincite $\left[\mathrm{Zn}_{5}\left(\mathrm{CO}_{3}\right)_{2}(\mathrm{OH})_{6}\right]$ are the detected corrosion products on zinc surfaces exposed in rural atmospheres. The zinc surface corrosion layers show isolated white products (zincite) on a generalized and relatively uniform clear grey layer (hydrozincite) (Figure 5(a)).

(iii) Pitting corrosion is observed (Figure 5(b)), possibly as a consequence of particulate settlement causing corrosion attack on zinc due to differential aeration. This feature was also observed by Askey et al. [56].

$\mathrm{SO}_{2}$-Polluted Atmospheres $\left(\mathrm{S}_{0} \mathrm{P}_{1}, \mathrm{~S}_{0} \mathrm{P}_{2}\right)$ :

(i) In Sao Paulo $\left(57.8 \mathrm{mg} \cdot \mathrm{m}^{-2} \cdot \mathrm{d}^{-1}\right.$ of $\left.\mathrm{SO}_{2}\right)$ the characteristic morphology and nature of corrosion products, rounded agglomerates of smithsonite, are observed (Figure 6(a)).

Pure Marine Atmospheres $\left(S_{1} P_{0}, S_{2} P_{0}, S_{3} P_{0}\right)$ :

(i) In low $\mathrm{SO}_{2}$ polluted $\left(\leq 10 \mathrm{mg} \cdot \mathrm{m}^{-2} \cdot \mathrm{d}^{-1}\right.$ of $\left.\mathrm{SO}_{2}\right)$ marine atmospheres corrosion of zinc is a direct function of the chloride pollution level and TOW. $\mathrm{S}_{1} \mathrm{P}_{0}$ atmospheres showed zinc corrosion rates of $0.19-2.73 \mu \mathrm{m} \cdot \mathrm{y}^{-1}$ and corrosivity categories, based on first-year corrosion rates, of $\mathrm{C} 2-\mathrm{C} 4$. In these atmospheres, the corrosion products formed after one-year exposure were zincite and hydrozincite. Only after exposure at the site with the highest chloride deposition rate $\left(55.1 \mathrm{mg} \cdot \mathrm{m}^{-2} \cdot \mathrm{d}^{-1}\right.$ of $\left.\mathrm{Cl}^{-}\right)$very small simonkolleite crystals were detected during SEM observations.

Simonkolleite shows a similar structure to hydrozincite, differing only in its interlayer structure content [57]. Both products show a layered structure of zinc cations in octahedral and tetragonal configurations with a ratio of $3: 2$. Hydrozincite shows $\mathrm{OH}^{-}$ions as its interlayer content. Simonkolleite shows chlorine atoms localized on the corner of the zinc tetrahedron, electric neutrality through the $\mathrm{H}-\mathrm{Cl}$ bonds remaining relatively weak. It displays hexagonal cells as its 
Table 6: MICAT test sites characteristics. Data for zinc.

\begin{tabular}{|c|c|c|c|c|c|c|c|c|}
\hline \multirow[t]{2}{*}{$\begin{array}{l}\text { Type of } \\
\text { atmosphere } \\
\text { (Table 3) }\end{array}$} & \multirow[t]{2}{*}{$\begin{array}{c}\text { Id. } \\
\text { (Table 2) }\end{array}$} & \multirow[t]{2}{*}{ Name } & \multicolumn{2}{|c|}{$\begin{array}{l}\text { Deposition rate } \\
\left(\mathrm{mg} \cdot \mathrm{m}^{-2} \cdot \mathrm{d}^{-1}\right)\end{array}$} & \multirow[t]{2}{*}{$\begin{array}{l}\text { Time of } \\
\text { wetness } \\
\text { (TOW) }\end{array}$} & \multirow[t]{2}{*}{$\begin{array}{l}\text { 1st-year } \\
\text { corrosion } \\
\text { rate }(\mu \mathrm{m})\end{array}$} & \multirow[t]{2}{*}{$\begin{array}{c}\text { Atmospheric } \\
\text { corrosivity } \\
\text { (ISO 9223) } \\
{[24]}\end{array}$} & \multirow[t]{2}{*}{$\begin{array}{l}\text { Corrosion products } \\
\text { (see Table 7) }\end{array}$} \\
\hline & & & $\mathrm{Cl}^{-}$ & $\mathrm{SO}_{2}$ & & & & \\
\hline \multirow{18}{*}{$\mathrm{S}_{0} \mathrm{P}_{0}$} & 44 & Granada & $(*)$ & 6,2 & $\tau_{3}$ & 0,11 & $\mathrm{C} 2$ & $\mathrm{Z}, \mathrm{H}$ \\
\hline & 35 & Guayaquil & 1,5 & 3,0 & $\tau_{4}$ & 0,21 & $\mathrm{C} 2$ & Z \\
\hline & 4 & San Juan & $(*)$ & $(*)$ & $\tau_{3}$ & 0,21 & $\mathrm{C} 2$ & $\mathrm{Z}, \mathrm{H}$ \\
\hline & 59 & Arequipa & $(*)$ & $(*)$ & $\tau_{2}$ & 0,23 & $\mathrm{C} 2$ & $\mathrm{Z}, \mathrm{H}$ \\
\hline & 43 & Tortosa & $(*)$ & 5,3 & $\tau_{4}$ & 0,25 & $\mathrm{C} 2$ & $\mathrm{Z}, \mathrm{H}$ \\
\hline & 47 & Artíes & 1,7 & 9,0 & $\tau_{3}$ & 0,28 & $\mathrm{C} 2$ & $\mathrm{Z}, \mathrm{H}$ \\
\hline & 40 & León & $(*)$ & $(*)$ & $\tau_{3}$ & 0,37 & $\mathrm{C} 2$ & $\mathrm{Z}, \mathrm{H}$ \\
\hline & 60 & Cuzco & $(*)$ & $(*)$ & $\tau_{4}$ & 0,40 & $\mathrm{C} 2$ & $\mathrm{Z}, \mathrm{H}$ \\
\hline & 65 & Trinidad & 1,5 & 0,7 & $\tau_{4}$ & 0,55 & $\mathrm{C} 2$ & - \\
\hline & 6 & La Plata & $(*)$ & 6,9 & $\tau_{4}$ & 0,91 & C3 & $\mathrm{H}, \mathrm{Z}$ \\
\hline & 61 & Pucallpa & $(*)$ & $(*)$ & $\tau_{5}$ & 1,01 & $\mathrm{C} 3$ & $\mathrm{Z}, \mathrm{H}$ \\
\hline & 2 & V. Martelli & $(*)$ & 9,0 & $\tau_{4}$ & 1,19 & $\mathrm{C} 3$ & $\mathrm{Z}, \mathrm{H}$ \\
\hline & 14 & Belem & $(*)$ & $(*)$ & $\tau_{5}$ & 1,10 & C3 & - \\
\hline & 49 & Cuernavaca & $(*)$ & 7,9 & $\tau_{3}$ & 1,36 & C3 & - \\
\hline & 3 & Iguazú & $(*)$ & $(*)$ & $\tau_{5}$ & 1,36 & C3 & - \\
\hline & 16 & Brasilia & $(*)$ & $(*)$ & $\tau_{4}$ & 1,78 & C3 & $\mathrm{Z}, \mathrm{H}$ \\
\hline & 20 & San Pedro & $(*)$ & 0,6 & $\tau_{5}$ & 3,29 & $\mathrm{C} 4$ & Z \\
\hline & 21 & Cotové & $(*)$ & 0,3 & $\tau_{4}$ & 3,30 & $\mathrm{C} 4$ & Z \\
\hline \multirow{2}{*}{$\mathrm{S}_{0} \mathrm{P}_{1}$} & 48 & México & $(*)$ & 13.6 & $\tau_{3}$ & 0,82 & C3 & $\mathrm{Z}, \mathrm{H}$ \\
\hline & 50 & S.L. Potosí & $(*)$ & 18.9 & $\tau_{3}$ & 1.77 & $\mathrm{C} 3$ & Z \\
\hline $\mathrm{S}_{0} \mathrm{P}_{2}$ & 12 & São Paulo & $(*)$ & 57.8 & $\tau_{5}$ & 1.21 & $\mathrm{C} 3$ & $\mathrm{Z}, \mathrm{HZC}, \mathrm{H}$ \\
\hline \multirow{13}{*}{$\mathrm{S}_{1} \mathrm{P}_{0}$} & 67 & Melo & 3,8 & 0,7 & $\tau_{5}$ & 0,69 & $\mathrm{C} 2$ & - \\
\hline & 41 & El Pardo & 3,9 & 6,4 & $\tau_{4}$ & 0,19 & $\mathrm{C} 2$ & $\mathrm{Z}, \mathrm{H}$ \\
\hline & 7 & Caratinga & 5,8 & 1,3 & $\tau_{4}$ & 0,67 & $\mathrm{C} 2$ & Z \\
\hline & 64 & Pego & 6,0 & 7,9 & $\tau_{4}$ & 1,15 & C3 & Z \\
\hline & 46 & Labastida & 9,8 & 3,6 & $\tau_{4}$ & 0,31 & $\mathrm{C} 2$ & $\mathrm{Z}, \mathrm{H}$ \\
\hline & 25 & Sabanilla & 11,3 & 4,9 & $\tau_{5}$ & - & - & $\mathrm{H}, \mathrm{ZC}$ \\
\hline & 73 & Matanzas & 15,9 & 9,3 & $\tau_{4}$ & 2,73 & $\mathrm{C} 4$ & - \\
\hline & 74 & Barcelona,V & 21,8 & 1,5 & $\tau_{4}$ & 2,01 & C3 & - \\
\hline & 51 & Acapulco & 23,8 & 9,6 & $\tau_{4}$ & 1,79 & C3 & $\mathrm{S}, \mathrm{Z}, \mathrm{H}$ \\
\hline & 72 & Coro & 27,5 & 6,5 & $\tau_{4}$ & 0,30 & $\mathrm{C} 2$ & - \\
\hline & 71 & Punto Fijo & 31,0 & 5,0 & $\tau_{4}$ & 0,57 & $\mathrm{C} 2$ & - \\
\hline & 22 & Puntarenas & 33,4 & 7,1 & $\tau_{4}$ & - & - & $\mathrm{H}, \mathrm{HZC}$ \\
\hline & 1 & Camet & 55,1 & $(*)$ & $\tau_{5}$ & 1,63 & $\mathrm{C} 3$ & - \\
\hline \multirow{6}{*}{$\mathrm{S}_{2} \mathrm{P}_{0}$} & 70 & El Tablazo & 63,3 & 6,0 & $\tau_{4}$ & - & - & - \\
\hline & 11 & Ubatuba & 113 & 2,6 & $\tau_{4}$ & 7,07 & $\mathrm{C} 5$ & $\mathrm{~S}, \mathrm{H}$ \\
\hline & 69 & P. del Este & 144 & 4,0 & $\tau_{4}$ & 2,89 & $\mathrm{C} 4$ & - \\
\hline & 23 & Limón & 220 & 3,5 & $\tau_{5}$ & - & - & $\mathrm{H}, \mathrm{S}, \mathrm{HZC}$ \\
\hline & 75 & P. Cabello & - & $(*)$ & $\tau_{5}$ & 4,34 & C5 & - \\
\hline & 9 & A. do Cabo & 229 & 6,7 & $\tau_{4}$ & 4,87 & $\mathrm{C} 5$ & $\mathrm{Z}, \mathrm{S}$ \\
\hline $\mathrm{S}_{3} \mathrm{P}_{0}$ & 15 & Fortaleza & $>300$ & $(*)$ & $\tau_{4}$ & 5,46 & C5 & - \\
\hline
\end{tabular}


TABle 6: Continued.

\begin{tabular}{|c|c|c|c|c|c|c|c|c|}
\hline \multirow[t]{2}{*}{$\begin{array}{l}\text { Type of } \\
\text { atmosphere } \\
\text { (Table 3) }\end{array}$} & \multirow[t]{2}{*}{$\begin{array}{c}\text { Id. } \\
\text { (Table 2) }\end{array}$} & \multirow[t]{2}{*}{ Name } & \multicolumn{2}{|c|}{$\begin{array}{l}\text { Deposition rate } \\
\left(\mathrm{mg} \cdot \mathrm{m}^{-2} \cdot \mathrm{d}^{-1}\right)\end{array}$} & \multirow[t]{2}{*}{$\begin{array}{l}\text { Time of } \\
\text { wetness } \\
\text { (TOW) }\end{array}$} & \multirow[t]{2}{*}{$\begin{array}{l}1 \text { st-year } \\
\text { corrosion } \\
\text { rate }(\mu \mathrm{m})\end{array}$} & \multirow[t]{2}{*}{$\begin{array}{c}\text { Atmospheric } \\
\text { corrosivity } \\
\text { (ISO 9223) } \\
{[24]}\end{array}$} & \multirow[t]{2}{*}{$\begin{array}{l}\text { Corrosion products } \\
\text { (see Table 7) }\end{array}$} \\
\hline & & & $\mathrm{Cl}^{-}$ & $\mathrm{SO}_{2}$ & & & & \\
\hline \multirow{10}{*}{$\mathrm{S}_{1} \mathrm{P}_{1}$} & 42 & Barcelona, S & 4,4 & 16,7 & $\tau_{3}$ & 0,56 & $\mathrm{C} 2$ & $\mathrm{Z}, \mathrm{H}$ \\
\hline & 52 & Panamá & 9,8 & 21,7 & $\tau_{4}$ & 1,06 & $\mathrm{C} 3$ & - \\
\hline & 66 & Prado & 10,8 & 12,1 & $\tau_{4}$ & 1,10 & $\mathrm{C} 3$ & - \\
\hline & 26 & Ciq & 12,0 & 31,6 & $\tau_{4}$ & 1,20 & C3 & $\mathrm{S}, \mathrm{ZC}$ \\
\hline & 28 & Bauta & 6,4 & 16,4 & $\tau_{4}$ & 1,22 & $\mathrm{C} 3$ & $\mathrm{H}, \mathrm{S}$ \\
\hline & 8 & Ipatinga & 6,8 & 23,0 & $\tau_{4}$ & 1,23 & C3 & $\mathrm{Z}$ \\
\hline & 58 & San Borja & 20,0 & 29,0 & $\tau_{5}$ & 1,61 & C3 & $\mathrm{Z}, \mathrm{H}$ \\
\hline & 56 & Piura & $(*)$ & $(*)$ & $\tau_{3}$ & 1,63 & C3 & - \\
\hline & 29 & Cerrillos & 4,5 & 20,0 & $\tau_{4}$ & 1,77 & C3 & $\mathrm{Z}$ \\
\hline & 57 & V. Salvador & 38,0 & 18,0 & $\tau_{5}$ & 2,46 & $\mathrm{C} 4$ & $\mathrm{Z}, \mathrm{H}$ \\
\hline \multirow{5}{*}{$\mathrm{S}_{1} \mathrm{P}_{2}$} & 45 & Lagoas & 16,7 & 39,5 & $\tau_{4}$ & 0,45 & $\mathrm{C} 2$ & $\mathrm{Z}, \mathrm{H}$ \\
\hline & 10 & Cubatão & 8,1 & 54,5 & $\tau_{4}$ & 1,25 & $\mathrm{C} 3$ & $\mathrm{H}$ \\
\hline & 13 & Río Janeiro & 16,4 & 43,5 & $\tau_{4}$ & 1,47 & C3 & $\mathrm{H}$ \\
\hline & 31 & Idiem & 16,8 & 43.3 & $\tau_{5}$ & 3,93 & $\mathrm{C} 4$ & $\mathrm{Z}$ \\
\hline & 32 & Petrox & 12,8 & 65,2 & $\tau_{5}$ & 8,58 & $>\mathrm{C} 5$ & $\mathrm{Z}$ \\
\hline \multirow{3}{*}{$\mathrm{S}_{2} \mathrm{P}_{1}$} & 63 & Sines & 203 & 27,0 & $\tau_{4}$ & 4,03 & $\mathrm{C} 4$ & $\mathrm{H}, \mathrm{BZC}, \mathrm{S}$ \\
\hline & 19 & Isla Naval & 60,7 & 10,3 & $\tau_{5}$ & 5,89 & C5 & S \\
\hline & 27 & Cojímar & 104 & 22,5 & $\tau_{4}$ & 7,09 & $\mathrm{C} 5$ & $\mathrm{~S}, \mathrm{ZC}, \mathrm{H}$ \\
\hline $\mathrm{S}_{2} \mathrm{P}_{2}$ & 62 & Leixões & 97,6 & 69,2 & $\tau_{4}$ & 2,51 & $\mathrm{C} 4$ & $\mathrm{H}, \mathrm{S}, \mathrm{ZH}$ \\
\hline
\end{tabular}

(*) apparently olluted.

(-) not available.

TABLE 7: Zinc corrosion products identified in the MICAT project.

\begin{tabular}{|c|c|c|}
\hline Code & Name & Composition \\
\hline & Oxides & \\
\hline \multirow[t]{2}{*}{ Z } & Zincite & $\mathrm{ZnO}$ \\
\hline & Hydroxides & \\
\hline \multirow[t]{2}{*}{$\mathrm{ZH}$} & Zinc hydroxide & $\mathrm{Zn}(\mathrm{OH})_{2}$ \\
\hline & Carbonates & \\
\hline $\mathrm{ZC}$ & Smithsonite & $\mathrm{ZnCO}_{3}$ \\
\hline $\mathrm{H}$ & Hydrozincite & $\mathrm{Zn}_{5}\left(\mathrm{CO}_{3}\right)_{2}(\mathrm{OH})_{6}$ \\
\hline $\mathrm{HZC}$ & $\begin{array}{l}\text { Hydrated zinc } \\
\text { carbonate }\end{array}$ & $4 \mathrm{ZnO} \cdot \mathrm{CO}_{2} \cdot 4 \mathrm{H}_{2} \mathrm{O}$ \\
\hline \multirow[t]{2}{*}{$\mathrm{BZC}$} & $\begin{array}{l}\text { Basic zinc } \\
\text { carbonate }\end{array}$ & $\begin{array}{l}\mathrm{Zn}_{4} \mathrm{CO}_{3}(\mathrm{OH})_{6} \cdot \mathrm{H}_{2} \mathrm{O} \text { or } \\
\mathrm{ZnCO}_{3} \cdot 3 \mathrm{Zn}(\mathrm{OH})_{2} \cdot \mathrm{H}_{2} \mathrm{O}\end{array}$ \\
\hline & Chlorides & \\
\hline$S$ & Simonkolleite & $\mathrm{Zn}_{5}(\mathrm{OH})_{8} \mathrm{Cl}_{2} \cdot \mathrm{H}_{2} \mathrm{O}$ \\
\hline
\end{tabular}

main structure [58]. Many of the $\mathrm{S}_{1} \mathrm{P}_{0}$ atmospheres did not lead to simonkolleite formation, possibly owing to the relatively low $\mathrm{Cl}^{-}$content to substitute $\mathrm{OH}^{-}$ions in the hydrozincite structure, preferably in acidic or almost neutral media, simonkolleite being more stable at high chloride concentrations.

(ii) $\mathrm{S}_{2} \mathrm{P}_{0}$ atmospheres showed significantly higher zinc corrosion rates $\left(2.89-7.07 \mu \mathrm{m} \cdot \mathrm{y}^{-1}\right)$ and as a consequence higher corrosivity categories (C4 and C5), being hydrozincite and simonkolleite the common corrosion products. The atmospheres in this group with high TOWs $\left(\tau_{5}\right)$ yielded open structures of corrosion product layers with very good simonkolleite crystallization and consequently higher corrosivity categories (Figure 6(b)).

Mixed Marine Atmospheres $\left(S_{1} P_{1}, S_{1} P_{2}, S_{2} P_{1}, S_{2} P_{2}\right)$ :

(i) Marine atmospheres with $\mathrm{SO}_{2}$ deposition rates in excess of $10 \mathrm{mg} \cdot \mathrm{m}^{-2} \cdot \mathrm{d}^{-1}$ of $\mathrm{SO}_{2}$ never display any evidence of residual zinc sulphates on the surface of the corrosion product layers because even if they form they are always washed off by rainfall.

(ii) When $\mathrm{Cl}^{-}<60 \mathrm{mg} \cdot \mathrm{m}^{-2} \cdot \mathrm{d}^{-1}$ of $\mathrm{Cl}^{-}$, the corrosion products do not display any evidence of simonkolleite. Zinc corrosion rates vary between 0.45 (C2) and 8.58 (C5) $\mu \mathrm{m} \cdot \mathrm{y}^{-1}$, strongly depending on TOW and pollution levels. However, chloride pollution of more than $60 \mathrm{mg} \cdot \mathrm{m}^{-2} \cdot \mathrm{d}^{-1}$ of $\mathrm{Cl}^{-}$promotes the formation of simonkolleite.

\subsection{Atmospheric Corrosion of Copper}

3.4.1. Mechanisms [59]. Several stages may be identified in the evolution of the visual appearance of exposed copper from its initial state to its final patination. Prior to exposure to an outdoor atmosphere, new freshly cleaned copper is a salmon-pink colour, but after just a few weeks of exposure it turns a dull-brown shade. 


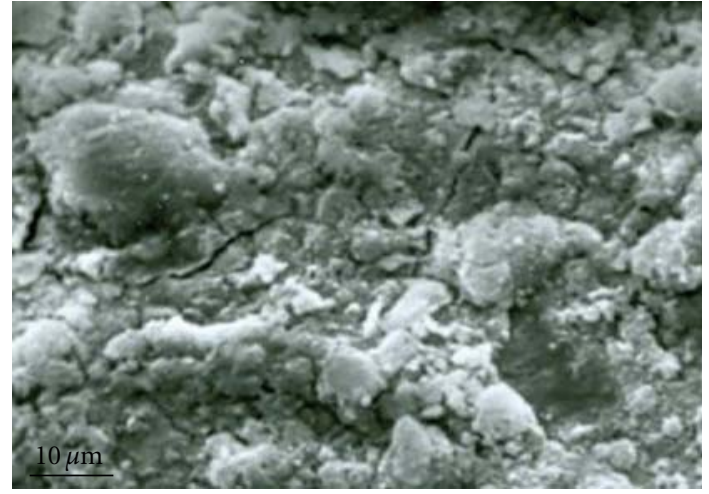

(a)

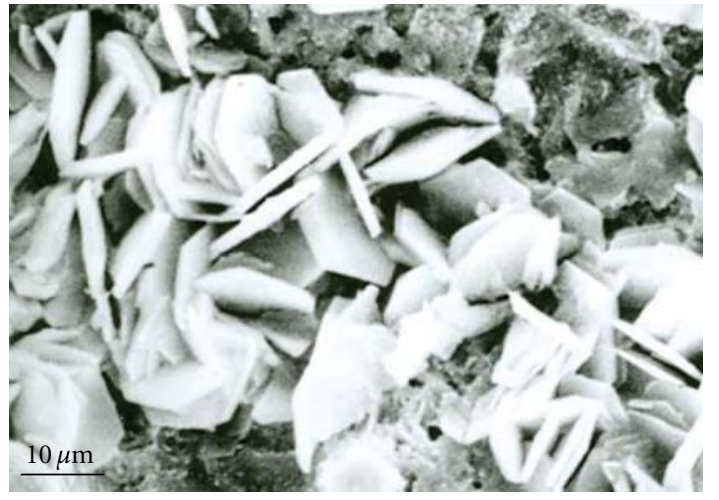

(b)

FIGURE 6: Morphology of corrosion product layers formed on zinc exposed in the $\mathrm{SO}_{2}$-polluted atmosphere of Sao Paulo (a) and marine atmosphere of Puerto Cabello (b).

At room temperature, copper in contact with clean air instantaneously becomes coated with a thin invisible film of cuprous oxide (cuprite) through a direct oxidation mechanism [60].

Copper corrosion in the atmosphere follows an electrochemical mechanism whereby the metal dissolves anodically forming cuprous and cupric ions:

$$
\begin{gathered}
\mathrm{Cu} \longrightarrow \mathrm{Cu}^{+}+\mathrm{e}^{-} \\
\mathrm{Cu} \longrightarrow \mathrm{Cu}^{2+}+2 \mathrm{e}^{-}
\end{gathered}
$$

In the first days of exposure to the atmosphere the copper surface often exhibits a mottled appearance (dark spots). These dark spots are comprised of submicron crystallites of a uniform size. With time the crystallites grow in size with a characteristic cubo-octahedral appearance.

With increased exposure time these spots increase in surface coverage and cause the specimens to change from their metallic colour to more familiar "copper" colours due to a thin surface oxide. After a few months the copper surface develops a uniform primary protective film of cuprite $\left(\mathrm{Cu}_{2} \mathrm{O}\right)$, which has a matt brown colour and continues to darken with exposure (blackening).

In the following corrosion stages, which can last up to $20 \mathrm{y}$ depending on the environmental conditions, a greenblue patina with a layered structure corresponding to brochantite (mainly rural and urban atmospheres) or atacamite (marine atmospheres) is formed. In the latter case the time to formation is considerably shorter. During this stage, although the copper looks brown, there is an initial "incubation period" in which brochantite forms on the cuprite surface as isolated islands that gradually join together.

Dissolution of $\mathrm{SO}_{2}$ in the moisture layer leads to the formation of sulphite $\left(\mathrm{SO}_{3}{ }^{2-}\right)$ and sulphate $\left(\mathrm{SO}_{4}{ }^{2-}\right)$ ions and acidification of the medium. In the presence of excess acidity $\left(\mathrm{H}^{+}\right)$cuprite dissolves according to the reaction:

$$
\mathrm{Cu}_{2} \mathrm{O}+2 \mathrm{H}^{+} \longrightarrow \mathrm{Cu}^{2+}+\mathrm{Cu}^{0}+\mathrm{H}_{2} \mathrm{O}
$$

A similar process takes place with the $\mathrm{Cl}^{-}, \mathrm{SO}_{4}{ }^{2-}$, and $\mathrm{H}^{+}$values typically found in meteorological precipitation.
Atacamite appears from the direct reaction of $\mathrm{Cl}^{-}$with $\mathrm{Cu}^{2+}$ ions according to the reaction:

$$
4 \mathrm{Cu}^{2+}+2 \mathrm{Cl}^{-}+6 \mathrm{H}_{2} \mathrm{O} \longrightarrow\left[\mathrm{Cu}_{4} \mathrm{Cl}_{2}(\mathrm{OH})_{6}\right]+6 \mathrm{H}^{+}
$$

and brocantite can form according to the reaction:

$$
4 \mathrm{Cu}^{2+}+6 \mathrm{H}_{2} \mathrm{O}+\mathrm{SO}_{4}{ }^{2-} \longrightarrow\left[\mathrm{Cu}_{4}\left(\mathrm{SO}_{4}\right)(\mathrm{OH})_{6}\right]+6 \mathrm{H}^{+}
$$

In rural and urban atmospheres, the formation of brochantite occurs as discrete isolated clumps of crystals on the cuprite base layer, with brochantite "islands" (Figure 7(a)) increasing in number and size with increasing exposure time [61].

Posnjakite $\left[\mathrm{Cu}_{4} \mathrm{SO}_{4}(\mathrm{OH})_{6} \cdot \mathrm{H}_{2} \mathrm{O}\right]$ is formed initially but is then either dissolved or converted to brochantite $\left[\mathrm{Cu}_{4} \mathrm{SO}_{4}(\mathrm{OH})_{6}\right]$ the most common sulphate-containing phase in copper patinas [62]. Weak indications of posnjakite are typically seen on specimen surfaces exposed to urban and rural atmospheres for one year or more.

With exposure time a continuous brochantite layer forms and hides the underlying cuprite layer, giving the specimens a green appearance (Figure 7(b)). This brochantite layer gradually increases in thickness.

In chloride environments (marine) the initial corrosion product phase to be formed is cuprite, with paratacamite $\left[\mathrm{Cu}_{2} \mathrm{Cl}(\mathrm{OH})_{3}\right]$, an isomorphic compound of atacamite, appears as a secondary phase growing on the cuprite. Atacamite also appears after longer exposures. Both atacamite and paratacamite present a green-blue colouring characteristic of the copper patinas formed in marine atmospheres (Figure 7(c)).

Once the patina is established it remains stable, and copper corrosion occurs at an ever diminishing rate. Patinated copper typically consists of (a) the underlying copper metal, (b) a thin layer (5-20 $\mu \mathrm{m})$ of cuprite, and (c) a top layer of basic copper sulphate (brochantite) or basic copper chloride (atacamite). 


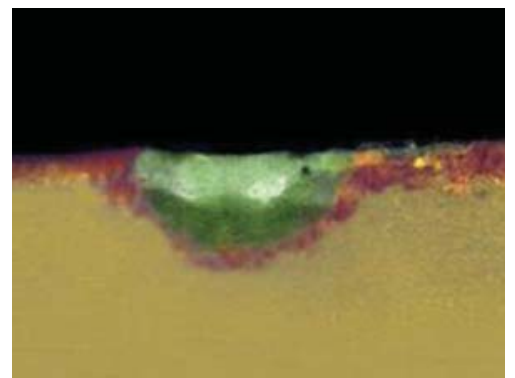

(a)

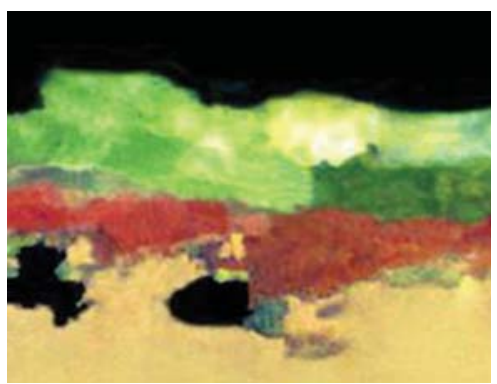

(b)

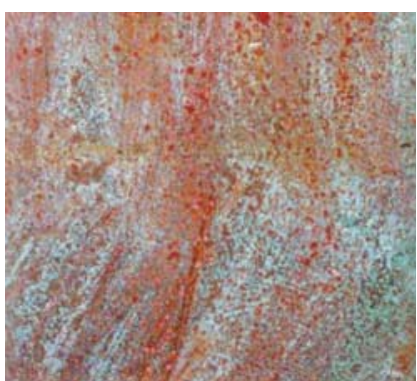

(c)

FIGURE 7: (a) Brochantite formation at discrete isolated clamps of crystals on the cuprite base layer formed in an urban atmosphere (crosssection view) [54]. (b) Brochantite formation on the cuprite base layer formed in a marine atmosphere (cross-section view) [54]. (c) Surface view of brochantite formation on the cuprite base layer formed in the marine atmosphere of Cojimar.

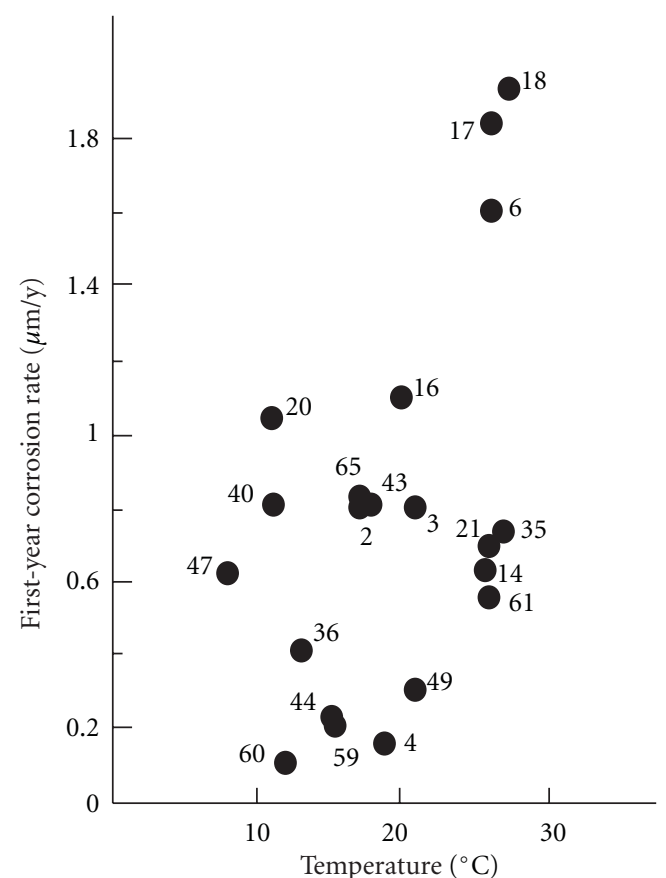

(a)

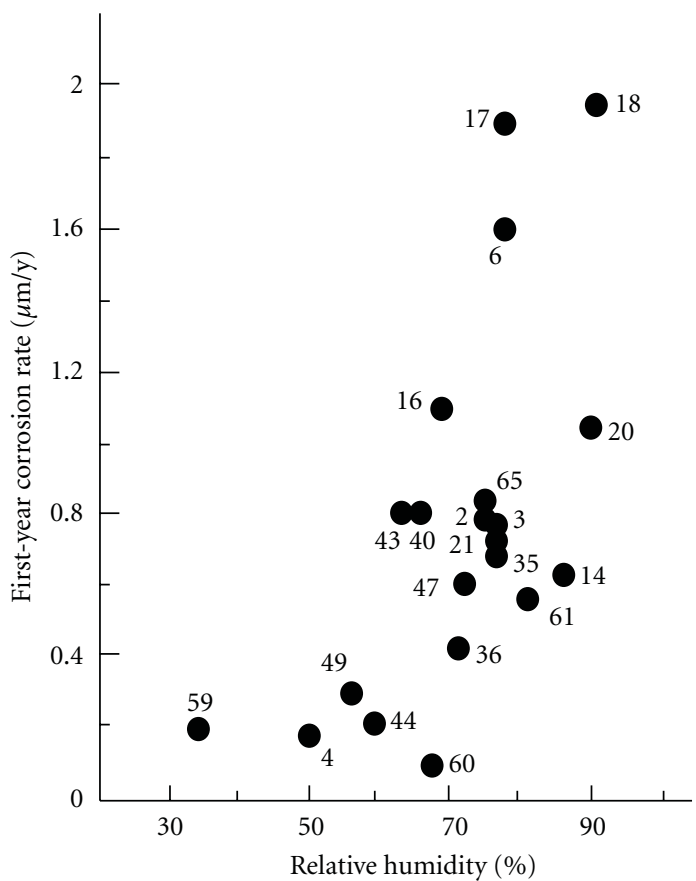

(b)

FIgURE 8: First-year copper corrosion rate versus temperature (a) and relative humidity (b) in rural atmospheres.

When environmental $\mathrm{SO}_{2}$ reaches a competitive level with the chloride aerosol the patina formed is a complex mixture of basic cupric chlorides (paratacamite and atacamite) and basic cupric sulphates (antlerite and brochantite).

3.4.2. Main Results Obtained in the MICAT Project. Table 8 displays information obtained in the MICAT project [10] and Table 9 gives a list of the main corrosion products identified.

There follows an analysis of copper behaviour in the MICAT project testing station network covering different types of atmospheres according to ISO 9223 (Table 3).

\section{Unpolluted Atmospheres $\left(S_{0} P_{0}\right)$ :}

(i) From a preliminary analysis of Table 8 , there is an enormous variation in the corrosion values found during the first year of exposure (from $0.09 \mu \mathrm{m} \cdot \mathrm{y}^{-1}$ in Cuzco to $1.57 \mu \mathrm{m} \cdot \mathrm{y}^{-1}$ in La Plata), which seems to indicate the importance of climatic conditions on the corrosion of this material in rural atmospheres.

To consider this question, an analysis was made of the annual average temperatures $(\mathrm{T})$ and relative humidities (RH) recorded at the test sites. To this end, Figure 8 displays the variation of first-year corrosion rates with the average annual $\mathrm{T}$ and $\mathrm{RH}$ values. The figures seem to suggest that low $\mathrm{T}$ and low $\mathrm{RH}$ tend to promote low copper corrosion rates, while high $\mathrm{RH}$ and high $\mathrm{T}$ (provided there is sufficient TOW of the metallic surface) tend to intensify copper corrosion in these types of atmospheres. This is in agreement with the observations of Kucera and Mattsson, who note that low temperatures and dryness of the atmosphere 
TABLE 8: MICAT test sites characteristics. Data for copper.

\begin{tabular}{|c|c|c|c|c|c|c|c|c|c|c|}
\hline \multirow{4}{*}{$\begin{array}{l}\text { Type of } \\
\text { atmosphere } \\
\text { (Table 3) }\end{array}$} & \multirow{4}{*}{$\begin{array}{c}\text { Id. } \\
\text { (Table 2) }\end{array}$} & \multirow{4}{*}{ Name } & Depo & ition rate & \multirow{4}{*}{$\mathrm{T}^{\circ} \mathrm{C}$} & \multirow{4}{*}{ RH \% } & \multirow{4}{*}{$\begin{array}{l}\text { Time of } \\
\text { wetness } \\
\text { (TOW) }\end{array}$} & \multirow{4}{*}{$\begin{array}{l}\text { 1st-year } \\
\text { corrosion } \\
\text { rate } \\
(\mu \mathrm{m})\end{array}$} & \multirow{4}{*}{$\begin{array}{l}\text { Atmospheric } \\
\text { corrosivity } \\
\text { (ISO 9223) } \\
{[24]}\end{array}$} & \multirow{4}{*}{$\begin{array}{l}\text { Corrosion products } \\
\text { (see Table 9) }\end{array}$} \\
\hline & & & & & & & & & & \\
\hline & & & \multicolumn{2}{|c|}{$\left(\mathrm{mg} \cdot \mathrm{m}^{-2} \cdot \mathrm{d}^{-1}\right)$} & & & & & & \\
\hline & & & $\mathrm{Cl}^{-}$ & $\mathrm{SO}_{2}$ & & & & & & \\
\hline \multirow{21}{*}{$\mathrm{S}_{0} \mathrm{P}_{0}$} & 60 & Cuzco & $(*)$ & $(*)$ & 12.2 & 67 & $\tau_{4}$ & 0,09 & $\mathrm{C} 1$ & - \\
\hline & 4 & San Juan & $(*)$ & $(*)$ & 18.8 & 50 & $\tau_{3}$ & 0,17 & $\mathrm{C} 2$ & $\mathrm{Cu}$ \\
\hline & 59 & Arequipa & $(*)$ & $(*)$ & 15.6 & 34 & $\tau_{2}$ & 0,20 & $\mathrm{C} 2$ & - \\
\hline & 44 & Granada & $(*)$ & 6,2 & 15.6 & 59 & $\tau_{3}$ & 0,22 & $\mathrm{C} 2$ & $\mathrm{Cu}$ \\
\hline & 49 & Cuernavaca & $(*)$ & 7,9 & 21.0 & 56 & $\tau_{3}$ & 0,30 & $\mathrm{C} 2$ & - \\
\hline & 36 & Riobamba & 1,1 & 1,2 & - & - & $\tau_{4}$ & 0,43 & $\mathrm{C} 2$ & - \\
\hline & 61 & Pucallpa & $(*)$ & $(*)$ & 26.1 & 81 & $\tau_{5}$ & 0,56 & $\mathrm{C} 2$ & - \\
\hline & 47 & Artíes & 1,7 & 9,0 & 7.8 & 72 & $\tau_{3}$ & 0,62 & $\mathrm{C} 3$ & $\mathrm{Cu}, \mathrm{Br}, \mathrm{Po}$ \\
\hline & 14 & Belem & $(*)$ & $(*)$ & 26.4 & 86 & $\tau_{5}$ & 0,64 & $\mathrm{C} 3$ & $\mathrm{Cu}, \mathrm{At}, \mathrm{Ca}$ \\
\hline & 35 & Guayaquil & 1,5 & 3,0 & 25.9 & 76 & $\tau_{4}$ & 0,71 & $\mathrm{C} 3$ & - \\
\hline & 21 & Cotové & $(*)$ & 0,3 & 27.0 & 76 & $\tau_{4}$ & 0,73 & $\mathrm{C} 3$ & $\mathrm{Cu}$ \\
\hline & 3 & Iguazú & $(*)$ & $(*)$ & 21.2 & 75 & $\tau_{5}$ & 0,77 & $\mathrm{C} 3$ & $\mathrm{Cu}$ \\
\hline & 2 & V. Martelli & $(*)$ & 9,0 & 16.9 & 74 & $\tau_{4}$ & 0,79 & $\mathrm{C} 3$ & $\mathrm{Cu}, \mathrm{Po}, \mathrm{Br}, \mathrm{At}$ \\
\hline & 40 & León & $(*)$ & $(*)$ & 11.2 & 65 & $\tau_{3}$ & 0,81 & C3 & $\mathrm{Cu}$ \\
\hline & 43 & Tortosa & $(*)$ & 5,3 & 17.4 & 63 & $\tau_{4}$ & 0,81 & $\mathrm{C} 3$ & $\mathrm{Cu}$ \\
\hline & 65 & Trinidad & 1,5 & 0,7 & 16.7 & 74 & $\tau_{4}$ & 0,83 & $\mathrm{C} 3$ & - \\
\hline & 20 & San Pedro & $(*)$ & 0,6 & 11.5 & 90 & $\tau_{5}$ & 1,05 & $\mathrm{C} 3$ & $\mathrm{Cu}$ \\
\hline & 16 & Brasilia & $(*)$ & $(*)$ & 20.4 & 68 & $\tau_{4}$ & 1,12 & $\mathrm{C} 3$ & $\mathrm{Cu}, \mathrm{Po}$ \\
\hline & 6 & La Plata & $(*)$ & 6,9 & 16.8 & 77 & $\tau_{4}$ & 1,57 & $\mathrm{C} 4$ & $\mathrm{Cu}$ \\
\hline & 17 & P. Alfonso & $(*)$ & $(*)$ & 25.9 & 77 & - & 1.86 & $\mathrm{C} 4$ & - \\
\hline & 18 & Porto Velho & $(*)$ & $(*)$ & 26.6 & 90 & - & 1.94 & $\mathrm{C} 4$ & 一 \\
\hline \multirow{2}{*}{$\mathrm{S}_{0} \mathrm{P}_{1}$} & 48 & México & $(*)$ & 12.0 & 15.4 & 64 & $\tau_{3}$ & 0.12 & $\mathrm{C} 3$ & $\mathrm{Cu}$ \\
\hline & 50 & S. L. Potosí & $(*)$ & 18.9 & 18.0 & 58 & $\tau_{3}$ & 0.54 & $\mathrm{C} 2$ & $\mathrm{Cu}$ \\
\hline $\mathrm{S}_{0} \mathrm{P}_{2}$ & 12 & São Paulo & $(*)$ & 57.8 & 19.6 & 75 & $\tau_{5}$ & 0.56 & $\mathrm{C} 4$ & $\mathrm{Cu}, \mathrm{Br}, \mathrm{Ca}$ \\
\hline \multirow{15}{*}{$\mathrm{S}_{1} \mathrm{P}_{0}$} & 67 & Melo & 3,8 & 0,7 & 17.4 & 80 & $\tau_{5}$ & 1,27 & $\mathrm{C} 3$ & - \\
\hline & 41 & El Pardo & 3,9 & 6,4 & 15.0 & 55 & $\tau_{4}$ & 0,81 & $\mathrm{C} 3$ & $\mathrm{Cu}, \mathrm{Po}$ \\
\hline & 7 & Caratinga & 5,8 & 1,3 & 21.2 & 74 & $\tau_{4}$ & 0,99 & $\mathrm{C} 3$ & $\mathrm{Cu}, \mathrm{Po}$ \\
\hline & 64 & Pego & 6,0 & 7,9 & 16.9 & 70 & $\tau_{4}$ & 1,43 & $\mathrm{C} 4$ & $\mathrm{Cu}, \mathrm{Po}$ \\
\hline & 46 & Labastida & 9,8 & 3,6 & 12.0 & 73 & $\tau_{4}$ & 0,95 & C3 & $\mathrm{Cu}$ \\
\hline & 25 & Sabanilla & 11,3 & 4,9 & 19.9 & 83 & $\tau_{5}$ & 1,23 & $\mathrm{C} 3$ & $\mathrm{Cu}$ \\
\hline & 73 & Matanzas & 15,9 & 9,3 & 27.7 & 75 & $\tau_{4}$ & 0,95 & $\mathrm{C} 3$ & - \\
\hline & 74 & Barcelona, $\mathrm{V}$ & 21,8 & 1,5 & 26.7 & 78 & $\tau_{4}$ & 0,35 & $\mathrm{C} 2$ & - \\
\hline & 51 & Acapulco & 23,8 & 9,6 & 24.6 & 80 & $\tau_{4}$ & 1,23 & $\mathrm{C} 3$ & $\mathrm{Cu}, \mathrm{At}$ \\
\hline & 39 & S. Cristóbal & 25,0 & 1,1 & 27.5 & 74 & - & 1,52 & $\mathrm{C} 4$ & - \\
\hline & 72 & Coro & 27,5 & 6,5 & 26.5 & 77 & $\tau_{4}$ & 2,35 & $\mathrm{C} 4$ & - \\
\hline & 71 & Punto Fijo & 31,0 & 5,0 & 27.6 & 76 & $\tau_{4}$ & 3,19 & C5 & - \\
\hline & 22 & Puntarenas & 33,4 & 7,1 & 28.0 & 80 & $\tau_{4}$ & 2,98 & C5 & $\mathrm{Cu}, \mathrm{At}$ \\
\hline & 37 & Salinas & 47,3 & 2,3 & 23.3 & 80 & $\tau_{4}$ & 2,33 & $\mathrm{C} 4$ & - \\
\hline & 1 & Camet & 55,1 & $(*)$ & 14.1 & 79 & $\tau_{5}$ & 2,23 & $\mathrm{C} 4$ & $\mathrm{Cu}$ \\
\hline \multirow{6}{*}{$\mathrm{S}_{2} \mathrm{P}_{0}$} & 11 & Ubatuba & 113 & 2,6 & 22.1 & 80 & $\tau_{4}$ & 3,29 & $\mathrm{C} 5$ & $\mathrm{Cu}, \mathrm{At}$ \\
\hline & 69 & P. del Este & 144 & 4,0 & 16.5 & 78 & $\tau_{4}$ & 2,51 & $\mathrm{C} 4$ & - \\
\hline & 23 & Limón & 220 & 3,5 & 25.4 & 88 & $\tau_{5}$ & 3,68 & C5 & $\mathrm{Cu}, \mathrm{At}$ \\
\hline & 9 & A. do Cabo & 229 & 6,7 & 24.5 & 78 & $\tau_{4}$ & 4,12 & C5 & $\mathrm{Cu}, \mathrm{At}$ \\
\hline & 75 & P. Cabello & - & $(*)$ & 26.7 & 82 & $\tau_{5}$ & 4,50 & $\mathrm{C} 5$ & - \\
\hline & 70 & El Tablazo & 63,3 & 6,0 & 27.7 & 77 & $\tau_{4}$ & 5,80 & $>\mathrm{C} 5$ & - \\
\hline
\end{tabular}


TABle 8: Continued.

\begin{tabular}{|c|c|c|c|c|c|c|c|c|c|c|}
\hline \multirow{3}{*}{$\begin{array}{l}\text { Type of } \\
\text { atmosphere } \\
\text { (Table 3) }\end{array}$} & \multirow{3}{*}{$\begin{array}{c}\text { Id. } \\
\text { (Table 2) }\end{array}$} & \multirow{3}{*}{ Name } & \multicolumn{2}{|c|}{ Deposition rate } & \multirow{3}{*}{$\mathrm{T}^{\circ} \mathrm{C}$} & \multirow{3}{*}{ RH \% } & \multirow{3}{*}{$\begin{array}{l}\text { Time of } \\
\text { wetness } \\
\text { (TOW) }\end{array}$} & \multirow{3}{*}{$\begin{array}{l}\text { 1st-year } \\
\text { corrosion } \\
\text { rate } \\
(\mu \mathrm{m})\end{array}$} & \multirow{3}{*}{$\begin{array}{c}\text { Atmospheric } \\
\text { corrosivity } \\
\text { (ISO 9223) } \\
\text { [24] }\end{array}$} & \multirow{3}{*}{$\begin{array}{l}\text { Corrosion products } \\
\text { (see Table 9) }\end{array}$} \\
\hline & & & \multicolumn{2}{|c|}{$\left(\mathrm{mg} \cdot \mathrm{m}^{-2} \cdot \mathrm{d}^{-1}\right)$} & & & & & & \\
\hline & & & $\mathrm{Cl}^{-}$ & $\mathrm{SO}_{2}$ & & & & & & \\
\hline $\mathrm{S}_{3} \mathrm{P}_{0}$ & 15 & Fortaleza & $>300$ & $(*)$ & 26.4 & 74 & $\tau_{4}$ & 3,80 & C5 & $\mathrm{Cu}, \mathrm{Co}, \mathrm{At}, \mathrm{Po}$ \\
\hline \multirow{10}{*}{$\mathrm{S}_{1} \mathrm{P}_{1}$} & 42 & Barcelona, S & 4,4 & 16,7 & 16.1 & 61 & $\tau_{3}$ & 0,71 & $\mathrm{C} 3$ & $\mathrm{Cu}, \mathrm{Po}$ \\
\hline & 29 & Cerrillos & 4,5 & 20,0 & 14.2 & 71 & $\tau_{4}$ & 0,73 & $\mathrm{C} 3$ & $\mathrm{Cu}$ \\
\hline & 30 & Valparaíso & 10,0 & 23,6 & 14.0 & 82 & $\tau_{5}$ & 0,87 & $\mathrm{C} 3$ & - \\
\hline & 8 & Ipatinga & 6,8 & 23,0 & 23.2 & 90 & $\tau_{4}$ & 1,21 & $\mathrm{C} 3$ & $\mathrm{Cu}$ \\
\hline & 52 & Panamá & 9,8 & 21,7 & 26.9 & 71 & $\tau_{4}$ & 1,24 & $\mathrm{C} 3$ & - \\
\hline & 66 & Prado & 10,8 & 12,1 & 17.0 & 76 & $\tau_{4}$ & 1,38 & $\mathrm{C} 4$ & - \\
\hline & 26 & Ciq & 12,0 & 31,6 & 25.2 & 79 & $\tau_{4}$ & 1,45 & $\mathrm{C} 4$ & $\mathrm{Cu}$ \\
\hline & 58 & San Borja & 20,0 & 29,0 & 19.4 & 84 & $\tau_{5}$ & 1,62 & $\mathrm{C} 4$ & $\mathrm{Cu}$ \\
\hline & 28 & Bauta & 6,4 & 16,4 & 24.0 & 81 & $\tau_{4}$ & 1,80 & $\mathrm{C} 4$ & $\mathrm{Cu}, \mathrm{At}, \mathrm{An}, \mathrm{Br}, \mathrm{Po}$ \\
\hline & 57 & V. Salvador & 38,0 & 18,0 & 19.6 & 84 & $\tau_{5}$ & 1,98 & $\mathrm{C} 4$ & $\mathrm{Cu}$ \\
\hline \multirow{5}{*}{$\mathrm{S}_{1} \mathrm{P}_{2}$} & 45 & Lagoas & 16,7 & 39,5 & 15.9 & 70 & $\tau_{4}$ & 1,23 & C3 & $\mathrm{Cu}$ \\
\hline & 10 & Cubatao & 8,1 & 54,5 & 22.7 & 74 & $\tau_{4}$ & 2,86 & C5 & $\mathrm{Cu}, \mathrm{Br}, \mathrm{Ca}$ \\
\hline & 31 & Idiem & 16,8 & 43,3 & 12.2 & 82 & $\tau_{5}$ & 4,79 & C5 & $\mathrm{Cu}$ \\
\hline & 32 & Petrox & 12,8 & 65,2 & 12.2 & 82 & $\tau_{5}$ & 5,35 & C5 & $\mathrm{Cu}, \mathrm{Br}$ \\
\hline & 13 & Río Janeiro & 16,4 & 43,5 & 21.4 & 80 & $\tau_{4}$ & 7,01 & $>\mathrm{C} 5$ & $\mathrm{Cu}, \mathrm{Br}$ \\
\hline \multirow{3}{*}{$\mathrm{S}_{2} \mathrm{P}_{1}$} & 63 & Sines & 203 & 27,0 & 18.4 & 61 & $\tau_{4}$ & 3.61 & C5 & $\mathrm{Cu}, \mathrm{At}, \mathrm{La}$ \\
\hline & 19 & Isla Naval & 60,7 & 10,3 & 27.8 & 86 & $\tau_{5}$ & 4.72 & C5 & $\mathrm{Cu}$ \\
\hline & 27 & Cojímar & 104 & 22,5 & 25.1 & 79 & $\tau_{4}$ & 4.89 & C5 & $\mathrm{Cu}, \mathrm{At}$ \\
\hline $\mathrm{S}_{2} \mathrm{P}_{2}$ & 62 & Leixões & 97,6 & 69,2 & 17.0 & 59 & $\tau_{4}$ & 4.32 & C5 & $\mathrm{Cu}, \mathrm{Pa}, \mathrm{At}, \mathrm{Sc}, \mathrm{Cc}$ \\
\hline
\end{tabular}

$(*)$ apparently nonpolluted.

(一) not available.

considerably delay the time of formation of patinas on copper [28].

\section{$\mathrm{SO}_{2}$-Polluted Atmospheres $\left(S_{0} P_{1}, S_{0} P_{2}\right)$ :}

(i) According to Barton [63] it is necessary to reach a minimum $\mathrm{SO}_{2}$ level in the atmosphere $\left(\sim 60 \mathrm{mg} \cdot \mathrm{m}^{-2} \cdot \mathrm{d}^{-1}\right.$ of $\left.\mathrm{SO}_{2}\right)$ for this pollutant to significantly influence copper corrosion, provided there is humidity on the surface. This critical value coincides with that found in the Sao Paulo atmosphere $\left(57.8 \mathrm{mg} \cdot \mathrm{m}^{-2} \cdot \mathrm{d}^{-1}\right.$ of $\left.\mathrm{SO}_{2}\right)$.

(ii) Sao Paulo is a highly polluted Ibero-American city with a heavy road traffic. Volatil organic compounds (VOC) in the Sao Paulo atmosphere, mainly carboxylic acids, were measured by Souza et al. [64] Photochemical production appeared to be a very likely source of the gaseous acetic and formic acids, although direct emissions mainly motor exhaust of vehicles also contributed to their presence in air.

It is well known that copper is corroded in presence of organic acids $[62,65]$. In a recent research, Echevarría et al. [66] found that copper corrosion increased at high relative humidities and concentrations of propionic acid.

The appearance of cuprous sulphide (chalcocite, $\mathrm{Cu}_{2} \mathrm{~S}$ ) in the first year of exposure in the Sao Paulo atmosphere, which in subsequent years is transformed into cupric sulphur (covellite, $\mathrm{CuS}$ ), seems to indicate the presence in this atmosphere of considerable amounts of sulphide ions, and the conversion in time of brocantite into antlerite. The first transformation confirms the research of Vernon and Whitby [67] who suggest calcocite as an initial formation that subsequently oxidises to covellite. However, the conversion of brocantite into antlerite contradicts some evidence [61] which suggested the formation of antlerite in the first stages of patination, experimentally confirming the hypothesis formulated by Baboian and Cliver [68], according to which acid rain converts brocantite into less protective antlerite formations.

Pure Marine Atmospheres $\left(S_{1} P_{0}, S_{2} P_{0}, S_{3} P_{0}\right)$ :

(i) A critical threshold for atmospheric salinity, $\sim 20 \mathrm{mg} \cdot \mathrm{m}^{-2} \cdot \mathrm{d}^{-1}$ of $\mathrm{Cl}^{-}$, seems to differentiate copper behavior in these types of atmospheres. Below 
TABle 9: Copper corrosion products identified in the MICAT project.

\begin{tabular}{lcc}
\hline Code & Name & Composition \\
\hline & Oxides & \\
$\mathrm{Cu}$ & Cuprite & $\mathrm{Cu}_{2} \mathrm{O}$ \\
\hline & Sulphates & \\
$\mathrm{Sc}$ & Copper (II) sulphate & $\mathrm{CuSO}_{4} \cdot \mathrm{H}_{2} \mathrm{O}$ \\
$\mathrm{An}$ & Antlerite & $\mathrm{Cu}_{3}\left(\mathrm{SO}_{4}\right)(\mathrm{OH})_{4}$ \\
$\mathrm{Br}$ & Brochantite & $\mathrm{Cu}_{4}\left(\mathrm{SO}_{4}\right)(\mathrm{OH})_{6}$ \\
$\mathrm{La}$ & Langite & $\mathrm{Cu}_{4}\left(\mathrm{SO}_{4}\right)(\mathrm{OH})_{6} \cdot 2 \mathrm{H}_{2} \mathrm{O}$ \\
Po & Posnjakite & $\mathrm{Cu}_{4}\left(\mathrm{SO}_{4}\right)(\mathrm{OH})_{6} \cdot 2 \mathrm{H}_{2} \mathrm{O}$ \\
\hline & Chlorides & \\
$\mathrm{Cc}$ & Copper (II) chloride & $\mathrm{CuCl}(\mathrm{OH})$ \\
At & Atacamite & $\mathrm{Cu}_{2} \mathrm{Cl}(\mathrm{OH})_{3}$ \\
$\mathrm{~Pa}$ & Paratacamite & $\mathrm{Cu}_{2} \mathrm{Cl}(\mathrm{OH})_{3}$ \\
\hline & Sulphides & \\
$\mathrm{Ca}$ & Chalcocite & $\mathrm{Cu} \mathrm{S}^{2}$ \\
$\mathrm{Co}$ & Covellite & $\mathrm{CuS}$ \\
\hline
\end{tabular}

the threshold, copper behaves as in rural atmospheres with corrosion rates of $<2 \mu \mathrm{m} \cdot \mathrm{y}^{-1}$. Above the threshold, copper corrosion accelerates notably with atmospheric salinity.

(ii) In Figure 9, the variation of the first-year copper corrosion rate with salinity in pure marine atmospheres is shown. It must be pointed out that copper corrosion in atmospheres with salinities of $<20 \mathrm{mg} \cdot \mathrm{m}^{-2} \cdot \mathrm{d}^{-1}$ of $\mathrm{Cl}^{-}$is close to copper corrosion in rural atmospheres (an average of $0.77 \mu \mathrm{m} \cdot \mathrm{y}^{-1}$ ). Salinities $>20 \mathrm{mg} \cdot \mathrm{m}^{-2} \cdot \mathrm{d}^{-1} \mathrm{Cl}^{-}$notably accelerate copper attack.

(iii) Copper hydroxysulfates are frequently detected in the corrosion product layers, accompanying the basic copper chlorides typical of these types of atmospheres.

Mixed Marine Atmospheres $\left(S_{1} P_{1}, S_{1} P_{2}, S_{2} P_{1}, S_{2} P_{2}\right)$ :

(i) The presence of both pollutants $\left(\mathrm{Cl}^{-}\right.$and $\left.\mathrm{SO}_{2}\right)$ leads to the abundant formation of basic salts, both sulfates (brochantite) and chlorides (atacamite), which noticeably compact the corrosion product layers.

(ii) Copper corrosion also accelerates in these types of atmospheres after a critical threshold of $20 \mathrm{mg} \cdot \mathrm{m}^{-2} \cdot \mathrm{d}^{-1}$ of $\mathrm{Cl}^{-}$, increasing with $\mathrm{Cl}^{-}$and $\mathrm{SO}_{2}$ contents in the atmosphere.

(iii) Basic chlorides and sulfates coexist in the atmospheric corrosion products. The threshold of $20 \mathrm{mg} \cdot \mathrm{m}^{-2} \cdot \mathrm{d}^{-1}$ of $\mathrm{Cl}^{-}$defines what will be the main constituent of the patinas; below this value the predominant phase is basic sulfates and above it basic chlorides.

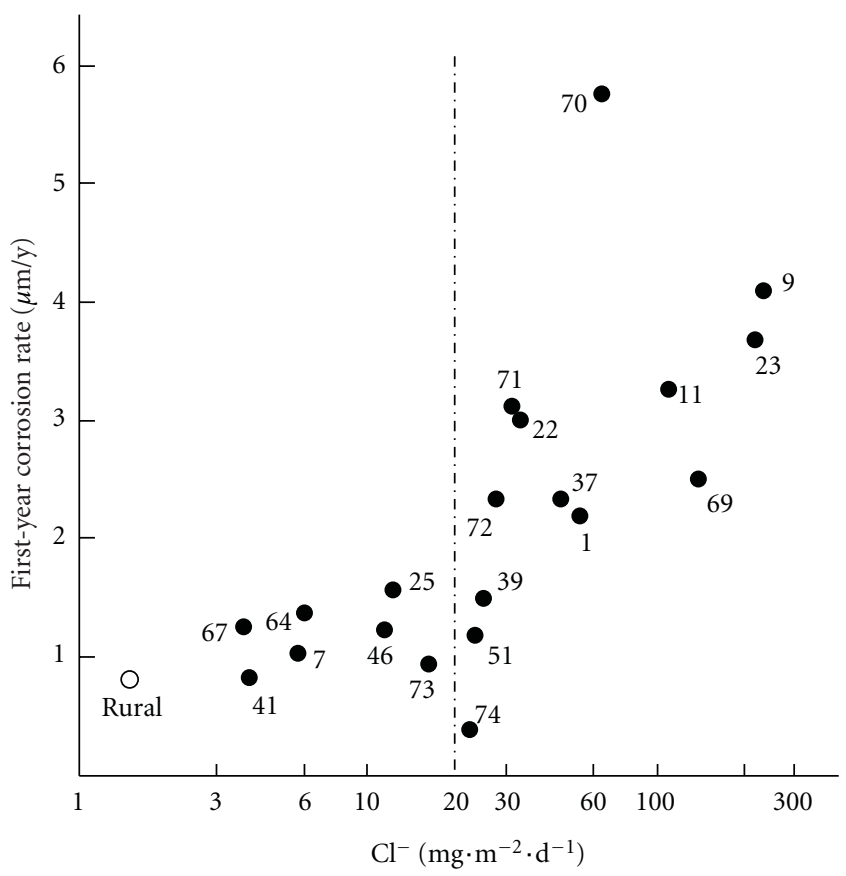

FIGURE 9: First-year copper corrosion rate versus $\mathrm{Cl}^{-}$deposition rate in marine $\left(\mathrm{S}_{1} \mathrm{P}_{0}, \mathrm{~S}_{2} \mathrm{P}_{0}\right.$, and $\left.\mathrm{S}_{3} \mathrm{P}_{0}\right)$ atmospheres. In the graph, the average value of corrosion rate in rural atmospheres $(\mathrm{O})$ is shown.

\subsection{Atmospheric Corrosion of Aluminium}

3.5.1. Mechanisms [69]. Unlike other metals, whose corrosion causes a general loss of thickness of the material, aluminium corrosion tends to be localised, with the formation of numerous cavities (pits) spread across the entire surface, leaving large areas of the metal between them intact. In this case the concept of mean penetration becomes meaningless, and it is preferable to express corrosion as mass loss per unit of surface area.

All studies agree that upon its initial exposure aluminium quickly forms a thin film of aluminium oxide. Under continued exposure this film may grow and be transformed into various other atmospheric products, $\gamma$-alumina $\left(\mathrm{Al}_{2} \mathrm{O}_{3}\right)$ is the first component formed upon exposure to the atmosphere, with an initial depth of $2-3 \mathrm{~nm}$ [70]. In a few months in the air, this oxide becomes covered by a thin layer of boehmite $[\gamma-\mathrm{AlOOH}]$, which is subsequently covered by bayerite $\left[\mathrm{Al}(\mathrm{OH})_{3}\right]$, also written as $\left[\mathrm{Al}_{2} \mathrm{O}_{3} \cdot 3 \mathrm{H}_{2} \mathrm{O}\right][71]$.

As with other metals, the atmospheric corrosion of aluminium is strongly influenced by the presence or absence of moisture. A crucial consequence of the existence of a water layer on the metal surface is that it provides a medium for the mobilisation of aluminium cations and also for deposited anions.

At the bottom of the pit the environment is acid, and aluminium acts anodically, oxidising according to the reaction: 
TABLE 10: MICAT test sites characteristics. Data for aluminium.

\begin{tabular}{|c|c|c|c|c|c|c|c|c|}
\hline \multirow[t]{2}{*}{$\begin{array}{l}\text { Type of } \\
\text { atmosphere } \\
\text { (Table 3) }\end{array}$} & \multirow[t]{2}{*}{$\begin{array}{c}\text { Id. } \\
\text { (Table 2) }\end{array}$} & \multirow[t]{2}{*}{ Name } & \multicolumn{2}{|c|}{$\begin{array}{l}\text { Deposition rate } \\
\left(\mathrm{mg} \cdot \mathrm{m}^{-2} \cdot \mathrm{d}^{-1}\right)\end{array}$} & \multirow[t]{2}{*}{$\begin{array}{l}\text { Time of } \\
\text { wetness } \\
\text { (TOW) }\end{array}$} & \multirow[t]{2}{*}{$\begin{array}{l}\text { 1st year } \\
\text { corrosion } \\
\text { rate }(\mu \mathrm{m})\end{array}$} & \multirow[t]{2}{*}{$\begin{array}{c}\text { Atmospheric } \\
\text { corrosivity } \\
\text { (ISO 9223) } \\
{[24]}\end{array}$} & \multirow[t]{2}{*}{$\begin{array}{l}\text { Corrosion products } \\
\text { (see Table 11) }\end{array}$} \\
\hline & & & $\mathrm{Cl}^{-}$ & $\mathrm{SO}_{2}$ & & & & \\
\hline \multirow{18}{*}{$\mathrm{S}_{0} \mathrm{P}_{0}$} & 59 & Arequipa & $(*)$ & $(*)$ & $\tau_{2}$ & 0,01 & $\mathrm{C} 1$ & - \\
\hline & 65 & Trinidad & 1,5 & 0,7 & $\tau_{4}$ & 0,01 & $\mathrm{C} 1$ & - \\
\hline & 60 & Cuzco & $(*)$ & $(*)$ & $\tau_{4}$ & 0,02 & $\mathrm{C} 1$ & $\mathrm{~N}$ \\
\hline & 35 & Guayaquil & 1,5 & 3,0 & $\tau_{4}$ & 0.03 & $\mathrm{C} 1$ & $\mathrm{~N}$ \\
\hline & 61 & Pucallpa & $(*)$ & $(*)$ & $\tau_{5}$ & 0.03 & $\mathrm{C} 1$ & $\mathrm{~N}$ \\
\hline & 44 & Granada & $(*)$ & 6,2 & $\tau_{3}$ & 0.04 & $\mathrm{C} 1$ & $\mathrm{~N}$ \\
\hline & 4 & San Juan & $(*)$ & $(*)$ & $\tau_{3}$ & 0,08 & $\mathrm{C} 1$ & $\mathrm{~N}$ \\
\hline & 43 & Tortosa & $(*)$ & 5,3 & $\tau_{4}$ & 0,08 & $\mathrm{C} 1$ & $\mathrm{~N}$ \\
\hline & 47 & Artíes & 1,7 & 9,0 & $\tau_{3}$ & 0,11 & $\mathrm{C} 1$ & $\mathrm{~N}$ \\
\hline & 2 & V. Martelli & $(*)$ & 9,0 & $\tau_{4}$ & 0,12 & $\mathrm{C} 1$ & $\mathrm{~N}$ \\
\hline & 40 & León & $(*)$ & $(*)$ & $\tau_{3}$ & 0,13 & $\mathrm{C} 1$ & $\mathrm{~N}$ \\
\hline & 21 & Cotové & $(*)$ & 0,3 & $\tau_{4}$ & 0,14 & $\mathrm{C} 1$ & - \\
\hline & 6 & La Plata & $(*)$ & 6,9 & $\tau_{4}$ & 0,15 & $\mathrm{C} 1$ & $\mathrm{~N}$ \\
\hline & 3 & Iguazú & $(*)$ & $(*)$ & $\tau_{5}$ & 0,20 & $\mathrm{C} 1$ & $\mathrm{~N}$ \\
\hline & 20 & S. Pedro & $(*)$ & 0,6 & $\tau_{5}$ & 0,20 & $\mathrm{C} 1$ & - \\
\hline & 14 & Belem & $(*)$ & $(*)$ & $\tau_{5}$ & 0,22 & $\mathrm{C} 1$ & $\mathrm{~N}$ \\
\hline & 49 & Cuernavaca & $(*)$ & 7,9 & $\tau_{3}$ & 0,24 & $\mathrm{C} 1$ & - \\
\hline & 16 & Brasilia & $(*)$ & $(*)$ & $\tau_{4}$ & 0,27 & $\mathrm{C} 1$ & $\mathrm{~N}$ \\
\hline \multirow{2}{*}{$\mathrm{S}_{0} \mathrm{P}_{1}$} & 48 & México & $(*)$ & 12 & $\tau_{3}$ & 0,12 & $\mathrm{C} 1$ & - \\
\hline & 50 & S.L. Potosí & $(*)$ & 18.9 & $\tau_{3}$ & 0.54 & $\mathrm{C} 2$ & - \\
\hline $\mathrm{S}_{0} \mathrm{P}_{2}$ & 12 & São Paulo & $(*)$ & 57.8 & $\tau_{5}$ & 0.56 & $\mathrm{C} 2$ & $\mathrm{~N}$ \\
\hline \multirow{15}{*}{$\mathrm{S}_{1} \mathrm{P}_{0}$} & 67 & Melo & 3,8 & 0,7 & $\tau_{5}$ & 0,06 & $\mathrm{C} 1$ & - \\
\hline & 41 & El Pardo & 3,9 & 6,4 & $\tau_{4}$ & 0,07 & $\mathrm{C} 1$ & $\mathrm{~N}$ \\
\hline & 7 & Caratinga & 5,8 & 1,3 & $\tau_{4}$ & 0,17 & $\mathrm{C} 1$ & $\mathrm{~N}$ \\
\hline & 64 & Pego & 6,0 & 7,9 & $\tau_{4}$ & 0,35 & $\mathrm{C} 2$ & $\mathrm{~N}$ \\
\hline & 46 & Labastida & 9,8 & 3,6 & $\tau_{4}$ & 0,18 & $\mathrm{C} 1$ & $\mathrm{~N}$ \\
\hline & 25 & Sabanilla & 11,3 & 4,9 & $\tau_{5}$ & 0,14 & $\mathrm{C} 1$ & $\mathrm{~N}$ \\
\hline & 73 & Matanzas & 15,9 & 9,3 & $\tau_{4}$ & 0,28 & $\mathrm{C} 1$ & - \\
\hline & 74 & Barcelona,V & 21,8 & 1,5 & $\tau_{4}$ & 0,16 & $\mathrm{C} 1$ & - \\
\hline & 39 & S.Cristóbal & 25,0 & 1,1 & - & 0,52 & $\mathrm{C} 2$ & $\mathrm{~N}$ \\
\hline & 72 & Coro & 27,5 & 6,5 & $\tau_{4}$ & 0,75 & C3 & - \\
\hline & 71 & Punto Fijo & 31,0 & 5,0 & $\tau_{4}$ & 0,49 & $\mathrm{C} 2$ & - \\
\hline & 51 & Acapulco & 23,8 & 9,6 & $\tau_{4}$ & 1,63 & C3 & - \\
\hline & 22 & Puntarenas & 33,4 & 7,1 & $\tau_{4}$ & 1,93 & C3 & $\mathrm{A}$ \\
\hline & 37 & Salinas & 47,3 & 2,3 & $\tau_{4}$ & 1,12 & $\mathrm{C} 3$ & - \\
\hline & 1 & Camet & 55,1 & $(*)$ & $\tau_{5}$ & 0,57 & $\mathrm{C} 2$ & $\mathrm{~N}$ \\
\hline \multirow{5}{*}{$\mathrm{S}_{2} \mathrm{P}_{0}$} & 11 & Ubatuba & 113 & 2,6 & $\tau_{4}$ & 1,17 & C3 & $\mathrm{A}$ \\
\hline & 69 & P. del Este & 144 & 4,0 & $\tau_{4}$ & 1,68 & $\mathrm{C} 3$ & - \\
\hline & 23 & Limón & 220 & 3,5 & $\tau_{5}$ & 0,86 & C3 & A \\
\hline & 9 & A. do Cabo & 229 & 6,7 & $\tau_{4}$ & 1,68 & C3 & A \\
\hline & 75 & P. Cabello & - & $(*)$ & $\tau_{5}$ & 1,64 & $\mathrm{C} 3$ & - \\
\hline $\mathrm{S}_{3} \mathrm{P}_{0}$ & 15 & Fortaleza & $>300$ & $(*)$ & $\tau_{4}$ & 1.58 & C3 & $\mathrm{A}$ \\
\hline
\end{tabular}


TABle 10: Continued.

\begin{tabular}{|c|c|c|c|c|c|c|c|c|}
\hline \multirow[t]{2}{*}{$\begin{array}{l}\text { Type of } \\
\text { atmosphere } \\
\text { (Table 3) }\end{array}$} & \multirow[t]{2}{*}{$\begin{array}{c}\text { Id. } \\
\text { (Table 2) }\end{array}$} & \multirow[t]{2}{*}{ Name } & \multicolumn{2}{|c|}{$\begin{array}{l}\text { Deposition rate } \\
\left(\mathrm{mg} \cdot \mathrm{m}^{-2} \cdot \mathrm{d}^{-1}\right)\end{array}$} & \multirow[t]{2}{*}{$\begin{array}{l}\text { Time of } \\
\text { wetness } \\
\text { (TOW) }\end{array}$} & \multirow[t]{2}{*}{$\begin{array}{l}\text { 1st year } \\
\text { corrosion } \\
\text { rate }(\mu \mathrm{m})\end{array}$} & \multirow[t]{2}{*}{$\begin{array}{c}\text { Atmospheric } \\
\text { corrosivity } \\
\text { (ISO 9223) } \\
\text { [24] }\end{array}$} & \multirow[t]{2}{*}{$\begin{array}{l}\text { Corrosion products } \\
\text { (see Table 11) }\end{array}$} \\
\hline & & & $\mathrm{Cl}^{-}$ & $\mathrm{SO}_{2}$ & & & & \\
\hline \multirow{10}{*}{$\mathrm{S}_{1} \mathrm{P}_{1}$} & 66 & Prado & 10,8 & 12,1 & $\tau_{4}$ & 0,27 & $\mathrm{C} 1$ & - \\
\hline & 8 & Ipatinga & 6,8 & 23,0 & $\tau_{4}$ & 0,39 & $\mathrm{C} 2$ & $\mathrm{~A}$ \\
\hline & 52 & Panamá & 9,8 & 21,7 & $\tau_{4}$ & 0,43 & $\mathrm{C} 2$ & - \\
\hline & 42 & Barcelona, S & 4,4 & 16,7 & $\tau_{4}$ & 0,68 & C3 & $\mathrm{N}$ \\
\hline & 29 & Cerrillos & 4,5 & 20,0 & $\tau_{4}$ & 0,68 & C3 & $\mathrm{N}$ \\
\hline & 28 & Bauta & 6,4 & 16,4 & $\tau_{4}$ & 0,99 & $\mathrm{C} 3$ & $\mathrm{~N}$ \\
\hline & 26 & Ciq & 12,0 & 31,6 & $\tau_{4}$ & 1,11 & $\mathrm{C} 3$ & $\mathrm{~N}$ \\
\hline & 58 & San Borja & 20,0 & 29,0 & $\tau_{5}$ & 1,32 & $\mathrm{C} 3$ & $\mathrm{~N}$ \\
\hline & 57 & V. Salvador & 38,0 & 18,0 & $\tau_{5}$ & 1,57 & $\mathrm{C} 3$ & $\mathrm{~N}$ \\
\hline & 30 & Valparaíso & 10 & 23.6 & $\tau_{5}$ & 3.56 & $\mathrm{C} 4$ & - \\
\hline \multirow{5}{*}{$\mathrm{S}_{1} \mathrm{P}_{2}$} & 45 & Lagoas & 16,7 & 39,5 & $\tau_{4}$ & 0,33 & $\mathrm{C} 2$ & $\mathrm{~N}$ \\
\hline & 13 & Río Janeiro & 16,4 & 43,5 & $\tau_{4}$ & 0,74 & $\mathrm{C} 3$ & A \\
\hline & 10 & Cubatão & 8,1 & 54,5 & $\tau_{4}$ & 0,78 & $\mathrm{C} 3$ & A \\
\hline & 31 & Idiem & 16,8 & 43.3 & $\tau_{5}$ & 5,21 & C5 & - \\
\hline & 32 & Petrox & 12,8 & 65,2 & $\tau_{5}$ & 5,43 & $\mathrm{C} 5$ & - \\
\hline \multirow{3}{*}{$\mathrm{S}_{2} \mathrm{P}_{1}$} & 19 & Isla Naval & 60,7 & 10,3 & $\tau_{5}$ & 1.67 & $\mathrm{C} 3$ & $\mathrm{~N}$ \\
\hline & 27 & Cojímar & 104 & 22,5 & $\tau_{4}$ & 3.01 & $\mathrm{C} 4$ & $\mathrm{~N}$ \\
\hline & 63 & Sines & 203 & 27,0 & $\tau_{4}$ & 3.79 & $\mathrm{C} 4$ & $\mathrm{~A}, \mathrm{Sb}$ \\
\hline $\mathrm{S}_{2} \mathrm{P}_{2}$ & 62 & Leixões & 97,6 & 69,2 & $\tau_{4}$ & 4.09 & $\mathrm{C} 4$ & $\mathrm{~A}, \mathrm{Sb}, \mathrm{Ca}$ \\
\hline
\end{tabular}

$(*)$ apparently nonpolluted.

(-) not available

(N) not detected any corrosion product.

TABLE 11: Aluminium corrosion products identified in the MICAT project.

\begin{tabular}{llc}
\hline Code & Name & Composition \\
\hline & Oxides & \\
$\mathrm{A}$ & Alumina & $\gamma-\mathrm{Al}_{2} \mathrm{O}_{3}$ \\
\hline & Sulphates & \\
$\mathrm{Sb}$ & $\begin{array}{c}\text { Aluminium basic } \\
\text { sulphate }\end{array}$ & $\mathrm{Al}_{x}\left(\mathrm{SO}_{4}\right)_{y}(\mathrm{OH})_{z}$ \\
\hline & Chlorides & \\
$\mathrm{Ca}$ & Aluminium chloride & $\mathrm{AlCl}_{3} \cdot 6 \mathrm{H}_{2} \mathrm{O}$ \\
\hline
\end{tabular}

The pit edges act as cathodes and the environment there is alkaline, giving rise to the cathodic reaction as in (2).

$\mathrm{Al}^{3+}$ ions, which are practically insoluble in water, combine with oxyhydryl ions from the dissociation of water to form aluminium hydroxide $\left[\mathrm{Al}(\mathrm{OH})_{3}\right]$ :

$$
\mathrm{Al}^{3+}+3 \mathrm{OH}^{-} \longrightarrow \mathrm{Al}(\mathrm{OH})_{3}
$$

Aluminium hydroxide is not soluble and precipitates in the form of a gelatinous white mass, normally known as alumina, although generally it is bayerite.
There is agreement that the normal corrosion reaction consists of combining with water to form aluminium hydroxide (which constitutes the corrosion product and covers the pit in the form of voluminous bulges) and hydrogen [72]:

$$
2 \mathrm{Al}+6 \mathrm{H}_{2} \mathrm{O} \longrightarrow 2\left[\mathrm{Al}(\mathrm{OH})_{3}\right]+3 \mathrm{H}_{2}
$$

The formation of hydrogen gas and its accumulation in the outermost strata of the base aluminium gives rise to the formation of blisters on the metallic surface, which coincide with the existence of pitting of the base aluminium.

The formation of pits on the surface is the most common type of corrosion found in aluminium alloys exposed to the atmosphere, above all in marine atmospheres. In the case of certain highly aggressive industrial atmospheres there are references which indicate the possibility of generalised attack.

The effect of the relative humidity (RH) of the air is of little consideration when aluminium is exposed to pure atmospheres. In fact, the corrosion of aluminium and its alloys depends primordially on the atmosphere being contaminated (in general by sulphur dioxide or chlorides), and only in such cases does the time of wetness intervene decisively in the corrosion process.

Little is known about the influence of temperature on the atmospheric corrosion of aluminium. According to Mikhailovskii et al. [73], temperature variations seem to have 


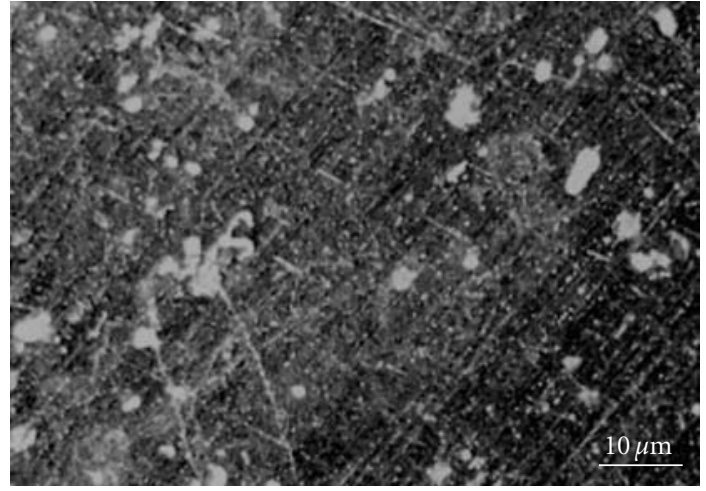

(a)

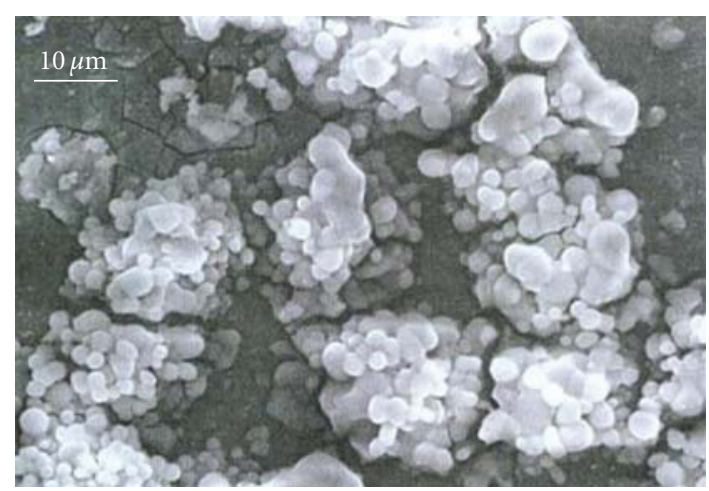

(c)

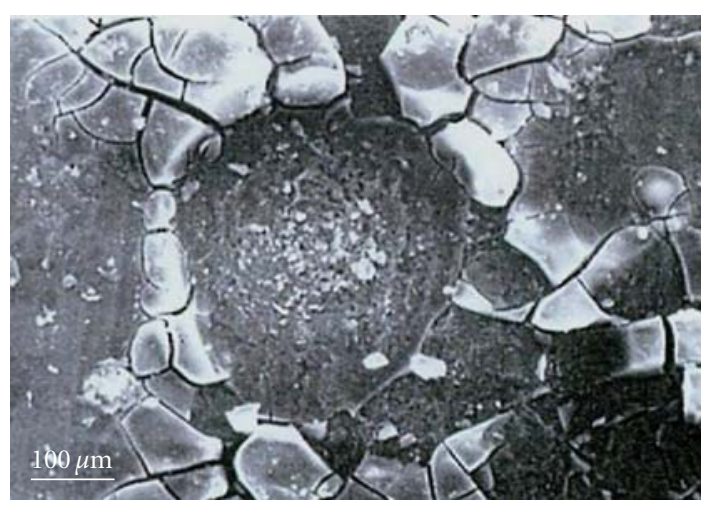

(b)

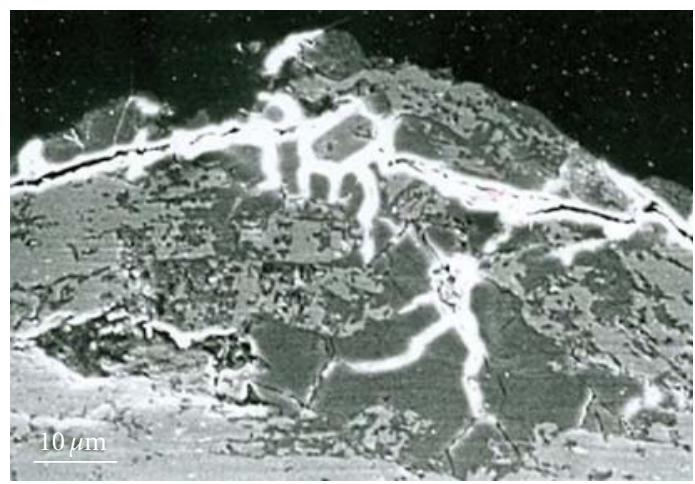

(d)

Figure 10: (a) Soiling of aluminium surface by dust particles. (b) Pitting of aluminium surface caused by sea-borne chlorides. Great formation of corrosion products (c) and strong pitting (d) caused by severe attack of aluminium in $\mathrm{SO}_{2}$-polluted marine atmospheres.

little influence on the corrosion of aluminium and its alloys over a broad temperature range when the surface is wetted by precipitated humidity (rain, fog, dew).

From an analysis of the available information [74] it is seen that the corrosion of aluminium is considerably accelerated in industrial atmospheres. This conclusion is in line with Speeding [75], who reports that the aluminium corrosion rate is seven-times higher in an industrial atmosphere than in a rural environment. The amount of $\mathrm{SO}_{2}$ absorbed on the aluminium surface increases notably with humidity, giving rise to the formation of sulphuric acid, which causes the destruction of the thin natural oxide film that spontaneously coats the metal, and thus accelerating the attack. Amorphous aluminium sulphate hydrate is observed to be the most abundant corrosion product on aluminium exposed to marine and industrial atmospheres [76].

Chloride ions are a significant cause of aluminium surface degradation in atmospheric exposure [77]. Chloride ions tend to perforate and destroy the natural oxide films that protect aluminium. Thus, according to Berukshitis and Klark [78], chlorides in the atmosphere constitute a specific medium for aluminium corrosion, which in their experiments was seen to be up to 22-times higher in a marine atmosphere than in a rural atmosphere.

3.5.2. Main Results Obtained in the MICAT Project. Table 10 displays information obtained in the MICAT project
[11-13], and Table 11 gives a list of the main corrosion products identified.

There follows an analysis of aluminium behaviour in the MICAT project testing station network covering different types of atmospheres according to ISO 9223 (Table 3).

Unpolluted Atmospheres $\left(S_{0} P_{0}\right)$. In unpolluted rural atmospheres aluminium does not present significant attack, only some soiling by dust particles (Figure 10(a)), loss of shine, and perhaps some isolated pitting, preferentially on the downward surfaces protected from the rain not detected with the naked eye. The corrosion values found $\left(<0.30 \mathrm{~g} \cdot \mathrm{m}^{-2} \cdot \mathrm{y}^{-1}\right)$ are mainly a result of metal attack by the chemical reagent used for gravimetric weight loss determination rather than by the action of the atmosphere.

\section{$\mathrm{SO}_{2}$-Polluted Atmospheres $\left(\mathrm{S}_{0} P_{1}, S_{0} P_{2}\right)$ :}

(i) Unfortunately, the MICAT project involved a very small number of testing stations of this type: only two atmospheres corresponding to category $\mathrm{S}_{0} \mathrm{P}_{1}$ (Mexico City and San Luis Potosí) and one atmosphere corresponding to category $\mathrm{S}_{0} \mathrm{P}_{2}$ (Sao Paulo). With so few stations it is risky to make generalisations about aluminium behaviour in these atmospheres. Bearing this in mind, an indication is given of the most relevant findings, supplemented with other published information. 
Aluminium attack in these two types of atmospheres, although significant, is only low $\left(<0.6 \mathrm{~g} \cdot \mathrm{m}^{-2} \cdot \mathrm{y}^{-1}\right)$, which may indicate that $\mathrm{SO}_{2}$ in the atmosphere does not have a significant effect on the atmospheric corrosion of aluminium at concentrations below $60 \mathrm{mg} \cdot \mathrm{m}^{-2} \cdot \mathrm{d}^{-1}$ of $\mathrm{SO}_{2}$, confirming the experience of Rozenfeld [79], possibly due to the low adsorption of $\mathrm{SO}_{2}$ by aluminium surfaces [80].

As in the rural atmospheres, the presence of very small amounts of corrosion products, aggravated by their location at isolated points on the surface, hinders their identification by the analytical techniques used in this research.

Pure Marine Atmospheres $\left(S_{1} P_{0}, S_{2} P_{0}, S_{3} P_{0}\right)$. In pure marine atmospheres there seems to be a critical threshold for atmospheric salinity, around $20 \mathrm{mg} \cdot \mathrm{m}^{-2} \cdot \mathrm{d}^{-1} \mathrm{Cl}^{-}$, which differentiates the corrosion behavior of aluminium. Below this threshold aluminium behaves in a similar way as in rural atmospheres, that is, practical absence of attack. Above it, aluminium undergoes pitting from the first year of exposure (Figure 10(b)) being more ostensible the greater the atmospheric salinity.

Mixed Atmospheres $\left(S_{1} P_{1}, S_{1} P_{2}, S_{2} P_{1}, S_{2} P_{2}\right)$. Aluminium corrosion in mixed atmospheres (polluted by $\mathrm{Cl}^{-}$and $\mathrm{SO}_{2}$ ) depends both on the chloride concentration and the $\mathrm{SO}_{2}$ pollution level in the atmosphere. Aluminium attack can increase considerably Figures 10(c) and 10(d), undergoing strong pitting from the start of exposure. There is a synergic effect through the combined action of the two pollutants.

\section{General Conclusion}

The 72 Ibero-American Atmospheric testing stations, covering a broad spectrum of climatological and pollution conditions, were divided into subgroups according the classification of atmospheric aggressiveness (ISO 9223 [24]) as function of meteorological (TOW) and atmospheric pollution $\left(\mathrm{SO}_{2}\right.$ and $\left.\mathrm{Cl}^{-}\right)$. The groups were as follows: unpolluted atmospheres, $\mathrm{SO}_{2}$-polluted atmospheres, pure marine atmospheres, and mixed atmospheres.

In each of these subgroups and for each of the reference metals (low carbon steel, zinc, copper, and aluminium) the corrosion extent for the first year of exposure and the nature of the corrosion products formed were evaluated. Generalizations were made based on observed trends.

\section{Acknowledgment}

The authors wish to express their gratitude to the Programa Ibero-Americano de Ciencia y Tecnología para el Desarrollo (CYTED) for financial support granted for the international coordination of MICAT project.

\section{References}

[1] L. Uller and M. Morcillo, "The setting-up of an Iberoamerican map of atmospheric corrosion. MICAT Study-CYTED-D," in
Proceedings of the 11th International Corrosion Congress, vol. 2, pp. 2.35-2.45, Associazione Italiana di Metallurgia, Florence, Italy, 1990.

[2] L. Uller and M. Morcillo, "Mapa Iberoamericano de Corrosao Atmosférica. Projecto MICAT Estudo-CYTED-D," Corrosao e Proteccao de Materiais, vol. 10, pp. 7-12, 1991.

[3] M. Morcillo, L. Uller, B. Rosales et al., "Ibero-American map of atmospheric corrosiveness (MICAT). Preliminary results," Corrosao e Proteccao de Materiais, vol. 11, pp. 6-12, 1992.

[4] M. Morcillo, L. Uller, B. Rosales et al., "Ibero-American map of atmospheric corrosiveness (MICAT). Preliminary results," Revista Iberoamericana de Corrosión y Protección, vol. 23, p. 79, 1992.

[5] M. Morcillo, E. Almeida, B. Rosales, J. Uruchurtu, and M. Marrocos, Corrosion y Protección de Metales en las Atmósferas de Iberoamérica. Parte I-Mapas de Iberoamérica de Corrosividad Atmosférica (Proyecto MICAT, XV.1/CYTED), CYTED, Madrid, Spain, 1998.

[6] E. Almeida, M. Morcillo, B. Rosales, and M. Marrocos, "Atmospheric corrosion of mild steel Part I-rural and urban atmospheres," Materials and Corrosion, vol. 51, no. 12, pp. 859-864, 2000.

[7] E. Almeida, M. Morcillo, and B. Rosales, "Atmospheric corrosion of mild steel Part II-Marine atmospheres," Materials and Corrosion, vol. 51, no. 12, pp. 865-874, 2000.

[8] E. Almeida, M. Morcillo, and B. Rosales, "Atmospheric corrosion of zinc Part 1: Rural and urban atmospheres," British Corrosion Journal, vol. 35, no. 4, pp. 284-288, 2000.

[9] E. Almeida, M. Morcillo, and B. Rosales, "Atmospheric corrosion of zinc Part 2: Marine atmospheres," British Corrosion Journal, vol. 35, no. 4, pp. 289-296, 2000.

[10] M. Morcillo, E. Almeida, M. Marrocos, and B. Rosales, "Atmospheric corrosion of copper in Ibero-America," Corrosion, vol. 57, no. 11, pp. 967-980, 2001.

[11] M. Morcillo, E. Almeida, and B. Rosales, "Degradation of aluminium in rural atmospheres," Aluminium, vol. 76, 2000.

[12] M. Morcillo, E. Almeida, and B. Rosales, "Corrosion of aluminium in pure marine atmospheres," Aluminium, vol. 76, 2000.

[13] M. Morcillo, E. Almeida, and B. Rosales, "Corrosion of aluminium in $\mathrm{SO}_{2}$ - polluted marine atmospheres," Aluminium, vol. 76, 2000.

[14] M. Morcillo, "Atmospheric corrosion in Ibero-america: the MICAT project," in Atmospheric Corrosion, W. W. Kirk and H. H. Lawson, Eds., pp. 257-275, American Society for Testing and Materials, Philadelphia, Pa, USA, ASTM STP 1239, 1995.

[15] L. Mariaca-Rodriguez, E. Almeida, and A. de Bosquez, "Marine atmospheric corrosion of reference metals in tropical climates of Latin-America," in Marine Corrosion in Tropical Environments, S. W. Dean, G. H. D. Delgadillo, and J. B. Bushman, Eds., pp. 3-17, American Society Testing and Materials, West Conshohocken, PA, 2000.

[16] M. Morcillo, B. Chico, D. de la Fuente et al., "Atmospheric corrosion of reference metals in Antarctic sites," Cold Regions Science and Technology, vol. 40, no. 3, pp. 165-178, 2004.

[17] M. Morcillo, E. Almeida, B. Chico, and D. De la Fuente, "Analysis of ISO standard 9223 (classification of corrosivity of atmospheres) in the light of information obtained in the Ibero-America micat project," in Outdoor Atmospheric Corrosion, American Society for Testing and Materials, West Conshohocken, Pa, USA, ASTM STP 1421, 2002.

[18] M. Morcillo and S. Feliu, Mapas de España de Corrosividad Atmosférica, CYTED, Madrid, Spain, 1993. 
[19] B. M. Rosales, Mapas de Corrosividad Atmosférica de Argentina, CITEFA, Buenos Aires, Argentina, 1977.

[20] M. E. M. Almeida and M. G. S. Ferreira, Corrosao Atmosferica. Mapas de Portugal, INETI, Lisboa, Portugal, 1998.

[21] L. Mariaca, J. Genescá, J. Uruchurtu, and L. Salvador, Corrosividad Atmosférica (MICAT-México), Plaza y Valdés, México, 1999.

[22] D. Knotkova and L. Vrobel, "ISOCORRAG - the international testing program within ISO/TC 156/WG 4," in Proceedings of the 11th International Corrosion Congress, pp. 5.581-5.590, Associazione Italiana di Metallurgia, Florence, Italy, 1990.

[23] V. Kucera, A. T. Coote, J. F. Henriksen, D. Knotkova, C. Leygraf, and U. Reinhardt, "Effects of acidifying air pollutants on materials including historic and cultural monuments. An International cooperative programme within UNECE," in Proceedings of the 11th Internacional Corrosion Congress, vol. 2, pp. 2.433-2.442, Associazione Italiana di Metallurgia, Florence, Italy, 1990.

[24] ISO 9223, Corrosion of Metals and Alloys. Clasiffication of Corrosivity of Atmospheres, International Standard Organization, Geneve, Switzerland, 1991.

[25] ISO 9225, Corrosion of Metals and alloys. Corrosivity of Atmospheres. Methods of Measurement of Pollution, International Standards Organization, Geneve, Switzerland, 1991.

[26] ISO 9226, Corrosion of Metals and Alloys. Corrosivity of Atmospheres. Method for Determination of Corrosion Rate of Standard Specimens for the Evaluation of Corrosivity, International Standards Organization, Geneve, Switzerland, 1991.

[27] M. Morcillo, D. de la Fuente, I. Díaz, and H. Cano, "Atmospheric corrosion of mild steel. A review," Revista de Metalurgi$a$, vol. 47 , no. 5 , pp. $426-444,2011$.

[28] V. Kucera and E. Mattsson, "Atmospheric corrosion," in Corrosion Mechanisms, F. Mansfeld, Ed., pp. 211-284, Marcel Dekker, New York, NY, USA, 1987.

[29] H. Okada and H. Shimada, "Relation between manganese sulfides and rust initiation," Corrosion, vol. 30, pp. 97-101, 1974.

[30] E. S. Ayllón, S. L. Granese, C. Bonazzola, and B. Rosales, "Corrosión atmosférica de aleaciones de fe y $\mathrm{Zn}$ en ambientes poluidos.," Revista Iberoamericana de Corrosión y Protección, vol. 17, pp. 205-211, 1986.

[31] W. H. J. Vernon, "A laboratory study of the atmospheric corrosion of metals. Part II.-Iron: The primary oxide film. Part III.- the secondary product or rust (influence of sulphur dioxide, carbon dioxide, and suspended particles on the rusting of iron)," Transactions of the Faraday Society, vol. 31, pp. 1668-1700, 1935.

[32] M. Stratmann and J. Müller, "The mechanism of the oxygen reduction on rust-covered metal substrates," Corrosion Science, vol. 36, no. 2, pp. 327-359, 1994.

[33] U. R. Evans, "Electrochemical mechanism of atmospheric rusting," Nature, vol. 206, no. 4988, pp. 980-982, 1965.

[34] T. Misawa, K. Asami, K. Hashimoto, and S. Shimodaira, "The mechanism of atmospheric rusting and the protective amorphous rust on low alloy steel," Corrosion Science, vol. 14, no. 4, pp. 279-289, 1974.

[35] M. Stratmann, K. Bohnenkamp, and T. Ramchandran, "The influence of copper upon the atmospheric corrosion of iron," Corrosion Science, vol. 27, no. 9, pp. 905-926, 1987.

[36] U. R. Evans, "The economic advantages of a sound painting scheme," Transactions of the Institute of Metal Finishing, vol. 37, pp. 1-7, 1960.

[37] U. R. Evans and C. A. J. Taylor, "Mechanism of atmospheric rusting," Corrosion Science, vol. 12, no. 3, pp. 227-246, 1972.
[38] M. Stratmann, K. Bohnenkamp, and H. J. Engell, "An electrochemical study of phase-transitions in rust layers," Corrosion Science, vol. 23, no. 9, pp. 969-985, 1983.

[39] M. Stratmann and H. Streckel, "On the atmospheric corrosion of metals which are covered with thin electrolyte layers-I. Verification of the experimental technique," Corrosion Science, vol. 30, no. 6-7, pp. 681-696, 1990.

[40] M. Schwarz, "Untersuchungen über dir Wirkung des Eisen (II)-sulfates beim atmosphärischen Rosten una beim Unterrosten von Anstrichen. Teil I," Werkstoffe und Korrosion, vol. 16, no. 1, pp. 93-103, 1965.

[41] J. F. Henriksen, "The distribution of $\mathrm{NaCl}$ on Fe during atmospheric corrosion," Corrosion Science, vol. 9, no. 8, pp. 573-577, 1969.

[42] R. Ericsson, "Influence of sodium chloride on the atmospheric corrosion of steel," Werkstoffe und Korrosion, vol. 29, no. 6, pp. 400-403, 1978.

[43] F. Corvo, "Atmospheric corrosion of steel in a humid tropical climate. Influence of pollution, humidity, temperature, rainfall and sun radiation," Corrosion, vol. 40, no. 4, pp. 170-175, 1984.

[44] M. Morcillo, S. Flores, G. Salas, and M. Valencia, "An extremely low corrosion rate of steel in the atmosphere of Cuzco (Peru)," Atmospheric Environment. Part A, vol. 27, no. 13, pp. 1959-1962, 1993.

[45] F. Mansfeld and R. Vijayakumar, "Atmospheric corrosion behavior in Southern California," Corrosion Science, vol. 28, no. 9, pp. 939-946, 1988.

[46] T. E. Graedel, "On the involvement of $\mathrm{H}_{2} \mathrm{O}_{2}$ and $\mathrm{SO}_{2}$ in the atmospheric corrosion of steel," Journal of the Electrochemical Society, vol. 135, no. 4, pp. 1035-1036, 1988.

[47] D. de la Fuente, J. G. Castaño, and M. Morcillo, "Long-term atmospheric corrosion of zinc," Corrosion Science, vol. 49, no. 3, pp. 1420-1436, 2007.

[48] P. Quintana, L. Veleva, W. Cauich, R. Pomes, and J. L. Peña, "Study of the composition and morphology of initial stages of corrosion products formed on $\mathrm{Zn}$ plates exposed to the atmosphere of southeast Mexico," Applied Surface Science, vol. 99, no. 4, pp. 325-334, 1996.

[49] I. Odnevall and C. Leygraf, "Reaction sequences in atmospheric corrosion of zinc," in Atmospheric Corrosion, W. W. Kirk and H. H. Lawson, Eds., pp. 215-229, American Society Testing and Materials, West Conshohocken, Pa, USA, 1995.

[50] G. Schikorr, "Korrosionsverhalten von Zink und Zinküberzügen an der AtmosphäreVorgetragen auf der Diskussionstagung "Atmosphärische Korrosion der Metalle"," Werkstoffe und Korrosion, vol. 15, pp. 537-543, 1964.

[51] T. E. Graedel, "Corrosion mechanisms for zinc exposed to the atmosphere," Journal of the Electrochemical Society, vol. 136, no. 4, pp. C193-C203, 1989.

[52] V. E. Carter, "Atmospheric corrosion of non-ferrous metals," in Corrosion Processes, R. N. Parkins, Ed., pp. 77-113, Applied Science, London, UK, 1982.

[53] H. Guttman, "Effects of atmospheric factors on the corrosion of rolled zinc," in Metal Corrosion in the Atmosphere, pp. 223239, American Society for Testing and Materials, Philadelphia, Pa, USA, ASTM STP 435, 1968.

[54] J. E. Svensson and L. G. Johansson, "A laboratory study of the initial stages of the atmospheric corrosion of zinc in the presence of $\mathrm{NaCl}$; Influence of $\mathrm{SO}_{2}$ and $\mathrm{NO}_{2}$," Corrosion Science, vol. 34, no. 5, pp. 721-740, 1993.

[55] C. J. Slunder and W. K. Boyd, Zinc: Its Corrosion Resistance, ILZRO, New York, NY, USA, 1983. 
[56] A. Askey, S. B. Lyon, G. E. Thompson et al., "The effect of flyash particulates on the atmospheric corrosion of zinc and mild steel," Corrosion Science, vol. 34, no. 7, pp. 1055-1081, 1993.

[57] I. Odnevall, Atmospheric corrosion of field exposed zinc, Ph.D. thesis, Royal Institute of Technology, Stockholm, Sweden, 1994.

[58] J. R. Vilche, F. E. Varela, G. Acuña et al., "A survey of Argentinean atmospheric corrosion: I-Aluminium and zinc samples," Corrosion Science, vol. 37, no. 6, pp. 941-961, 1995.

[59] D. de la Fuente, J. Simancas, and M. Morcillo, "Morphological study of 16-year patinas formed on copper in a wide range of atmospheric exposures," Corrosion Science, vol. 50, no. 1, pp. 268-285, 2008.

[60] E. Mattsson and R. Holm, "Copper and copper alloys," in Metal Corrosion in the Atmosphere, pp. 187-210, American Society for Testing and Materials, Philadelphia, Pa, USA, ASTM STP 435, 1968.

[61] T. E. Graedel, K. Nassau, and J. P. Franey, "Copper patinas formed in the atmosphere-I. Introduction," Corrosion Science, vol. 27, no. 7, pp. 639-649, 1987.

[62] T. E. Graedel, "Copper patinas formed in the atmosphereII. A qualitative assessment of mechanisms," Corrosion Science, vol. 27, no. 7, pp. 721-740, 1987.

[63] K. Barton, "Personal Communication," in Corrosion in Natural Environments, D. Knotkova, B. Bosek, and J. Vlickova, Eds., p. 52, merican Society for Testing and Materials, Philadelphia, Pa, USA, ASTM STP 558, 1974.

[64] S. R. Souza, P. C. Vasconcellos, and L. R. F. Carvalho, "Low molecular weight carboxylic acids in an urban atmosphere: Winter measurements in São Paulo City, Brazil," Atmospheric Environment, vol. 33, no. 16, pp. 2563-2574, 1999.

[65] A. V. Echavarría, F. E. Echeverría, C. Arroyave, E. Cano, and J. M. Bastidas, "Carboxilic acids in the atmosphere and their effect on the degradation of metals," Corrosion Reviews, vol. 21, no. 5-6, pp. 395-413, 2003.

[66] A. Echavarría, F. Echeverría, H. Gil, and C. Arroyave, "Influence of environmental factors in the atmospheric corrosion of copper in the presence of propionic acid," Journal of the Chilean Chemical Society, vol. 54, no. 3, pp. 212-217, 2009.

[67] W. H. J. Vernon and L. Whitby, "The open-air corrosion of copper. Part II. The mineralogical relationships of corrosion products," Journal of the Institute of Metals, vol. 44, pp. 389408, 1930.

[68] R. Baboian and E. B. Cliver, "Corrosion on the statue of liberty," Materials Performance, vol. 25, no. 3, pp. 80-81, 1986.

[69] D. de la Fuente, E. Otero-Huerta, and M. Morcillo, "Studies of long-term weathering of aluminium in the atmosphere," Corrosion Science, vol. 49, no. 7, pp. 3134-3148, 2007.

[70] H. P. Godard, The Corrosion of Light Metals, John Wiley \& Sons, New York, NY, USA, 1967.

[71] M. S. Hunter and P. Fowle, "Natural and thermally formed oxide films on aluminum," Journal of the Electrochemical Society, vol. 103, pp. 482-485, 1656.

[72] H. P. Godard, "An insight into the corrosion behavior of aluminum," Materials Performance, vol. 20, no. 7, pp. 9-15, 1981.

[73] Y. N. Mikhailovskii, G. B. Klark, L. A. Shuvakhina, V. V. Agafonov, and N. I. Zhuravlena, "Calculation of atmospheric corrosion rate of aluminum and its alloys in various climatic zones according to meteorological parameters," Protection of Metals, vol. 9, no. 3, pp. 240-246, 1973.

[74] S. Feliu and M. Morcillo, Corrosión y Protección de los Metales en la Atmósfera, Barcelona, Spain, 1982.
[75] P. L. Spedding, "Corrosion by atmospheric sulphur dioxide ," Australasian Corrosion Engineering, vol. 15, no. 8, pp. 27-36, 1971.

[76] T. E. Graedel, "Corrosion mechanisms for aluminum exposed to the atmosphere," Journal of the Electrochemical Society, vol. 136, no. 4, pp. C204-C212, 1989.

[77] R. T. Foley, "Localized corrosion of aluminum alloys: a review," Corrosion, vol. 42, no. 5, pp. 277-288, 1986.

[78] G. K. Berukshitis and G. B. Klark, "Atmospheric corrosion of steel, zinc, cadmium, copper and aluminum in different coastal and continental regions," in Corrosion of Metal and Alloys, G. B. Tomashov and E. N. Mirolubev, Eds., pp. 281297, Israel Program for Scientific Translations, Jerusalem, Israel, 1966.

[79] I. L. Rozenfeld, Atmospheric Corrosion of Metals, NACE, Houston, Tex, USA, 1972.

[80] T. Sydberger and N. G. Vannerberg, "The influence of the relative humidity and corrosion products on the adsorption of sulfur dioxide on metal surfaces," Corrosion Science, vol. 12, no. 10, pp. 775-784, 1972. 

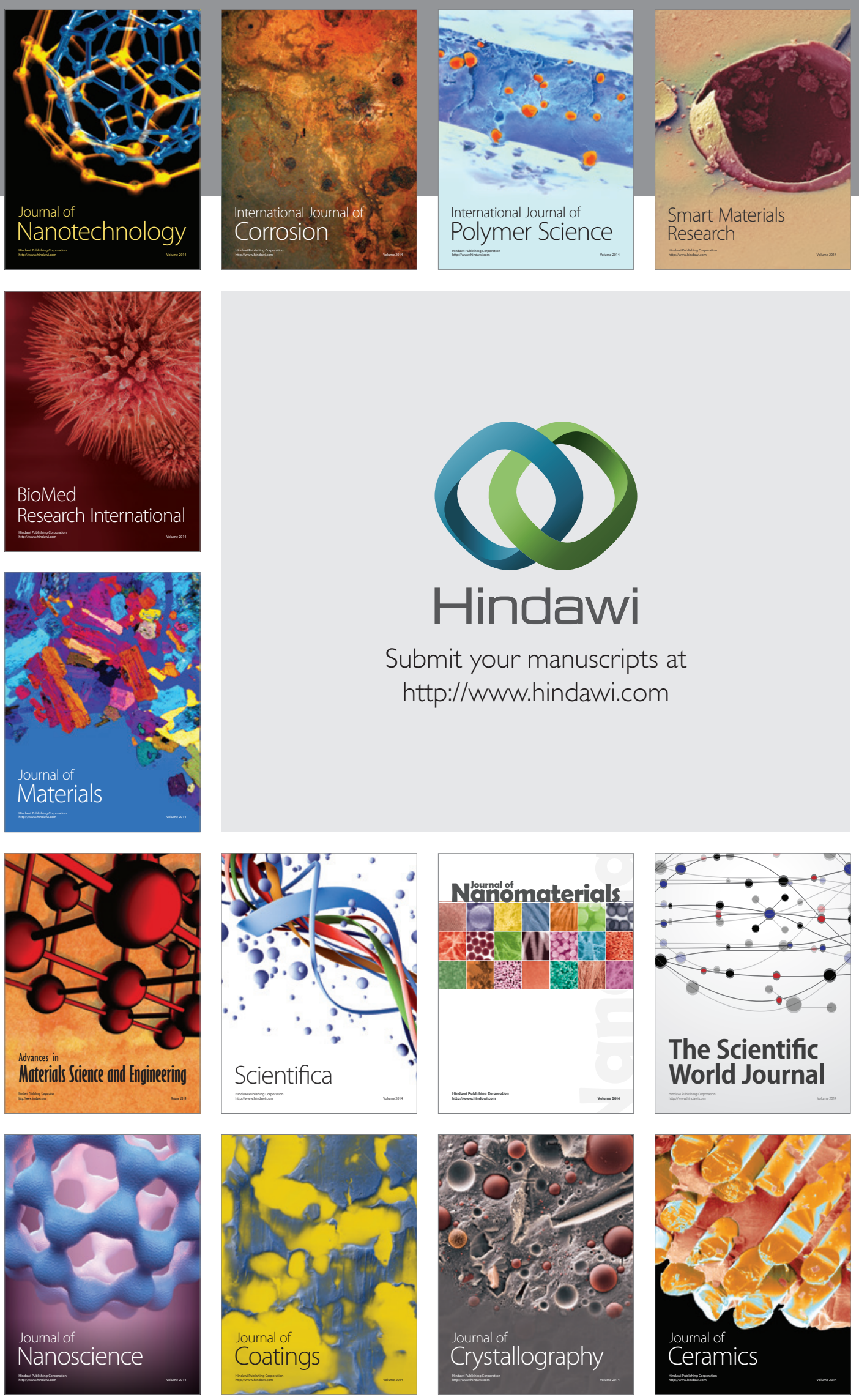

The Scientific World Journal

Submit your manuscripts at

http://www.hindawi.com

\section{World Journal}

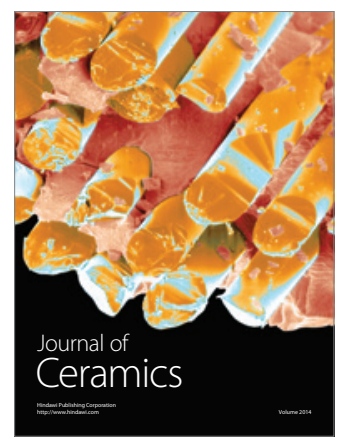

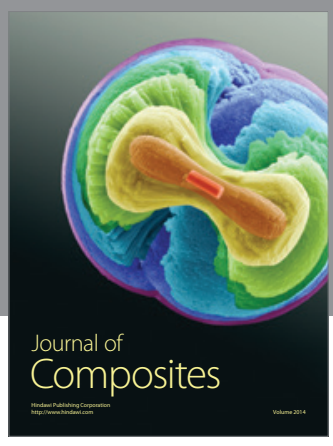
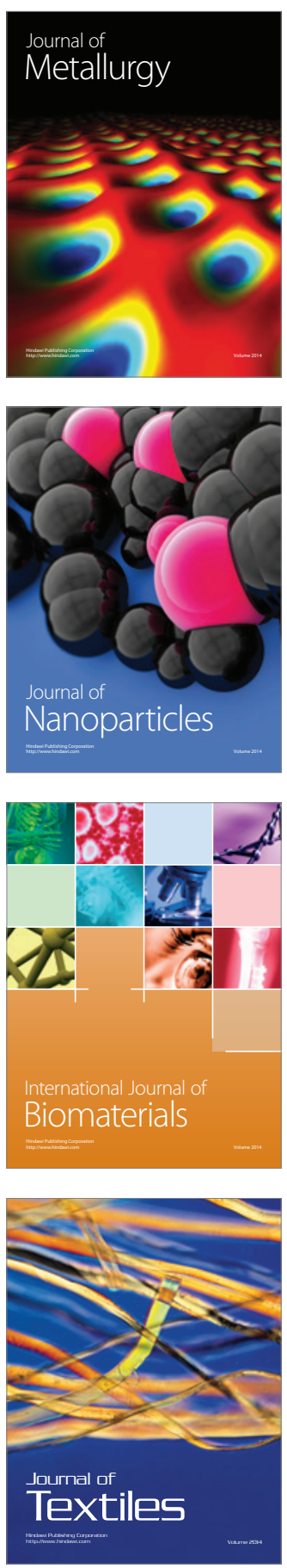